\title{
The influence of Atlantic climate variability on the long-term development of Mediterranean cold-water coral mounds (Alboran Sea, Melilla Mound Field)
}

Robin Fentimen ${ }^{1}$, Eline Feenstra ${ }^{1}$, Andres Rüggeberg ${ }^{1}$, Efraim Hall ${ }^{1}$, Valentin Rime ${ }^{1}$, Torsten 5 Vennemann $^{2}$, Irka Hajdas ${ }^{3}$, Antonietta Rosso ${ }^{4}$, David Van Rooij ${ }^{5}$, Thierry Adatte ${ }^{2}$, Hendrik Vogel $^{6}$, Norbert Frank ${ }^{7}$, Thomas Krengel ${ }^{7}$, Anneleen Foubert ${ }^{1}$

${ }^{1}$ Department of Geosciences, University of Fribourg, Fribourg, CH-1700, Switzerland

${ }^{2}$ Institute of Earth Surface Dynamics, University of Lausanne, Lausanne, CH-1015, Switzerland

${ }^{3}$ Laboratory of Ion Beam Physics, ETH Zürich, Zürich, CH-8093, Switzerland

$10{ }^{4}$ Department of Biological, Geological and Environmental Sciences, University of Catania, Catania, 95128, Italy

${ }^{5}$ Department of Geology, Ghent University, Ghent, 9000, Belgium

${ }^{6}$ Institute of Geological Sciences and Oeschger Centre for Climate Change Research, University of Bern, Bern, $\mathrm{CH}-$ 3012, Switzerland

${ }^{7}$ Institute of Environmental Physics, University of Heidelberg, Heidelberg, D-69120, Germany

Correspondence to: Robin Fentimen (robin.fentimen@unifr.ch)

\begin{abstract}
This study provides a detailed reconstruction of climatic events affecting a cold-water coral mound located within the East Melilla Coral Province (Southeast Alboran Sea) over the last $300 \mathrm{ky}$. Based on benthic foraminiferal assemblages, macrofaunal quantification, grain size analysis, sediment geochemistry, and foraminiferal stable isotope compositions, a reconstruction of environmental conditions prevailing in the region is proposed. The variations in planktonic and benthic $\delta^{18} \mathrm{O}$ values indicate that cold-water coral mound formation follows global climatic variability. Cold-water corals develop during both interglacial and glacial periods, although interglacial conditions would have allowed better proliferation. Environmental conditions during glacial periods, particularly during the Last Glacial Maximum, appear to better suit the ecological requirements of the erect cheilostome bryozoan Buskea dichotoma. Benthic foraminiferal assemblages suggest that high organic carbon flux characterized interglacial periods. Results from this study imply that increased influence of warm and moist Atlantic air masses during interglacial periods led to increased fluvial discharge, providing nutrients for cold-water corals. Important interglacial Atlantic Water mass inflow further promoted strong Alboran Gyres, and thus mixing between surface and intermediate water masses. Increased turbulence and nutrient supply would have hence provided suitable conditions for coral development. In contrast, benthic foraminiferal assemblages and grain size distributions suggest that the benthic environment received less organic matter during glacial periods, whilst bottom flow velocity was reduced in comparison to interglacial periods. During glacial periods, arid continental conditions combined to more stratified water masses caused a dwindling of coral communities in the southeastern Alboran Sea, although aeolian dust input may have allowed these to survive. In contrast to Northeast Atlantic counterparts, coral mound build-up in the southeastern Alboran Sea occurs during glacial as well as during interglacial periods and at very low aggradation rates (between 1 and $9 \mathrm{~cm}^{-k^{-1}}$ ). We propose that Buskea dichotoma plays an important role in long-term mound formation at the East Melilla Coral Province, noticeably during glacial periods.
\end{abstract}




\section{Introduction}

Cold-water coral (CWC) reefs are diverse ecosystems that are common on Earth (Freiwald et al., 2004; Roberts et al., 2009). The most important reef building CWC species in the Atlantic Ocean and Mediterranean Sea are the scleractinians Desmophyllum pertusum (formerly known as Lophelia pertusa, see Addamo et al., 2016) and Madrepora oculata (Roberts et al., 2009). These predominantly suspension-feeding organisms depend on nutrient supply and enhanced hydrodynamic regimes (White et al., 2005; Mienis et al., 2007; Carlier et al., 2009; Davies et al., 2009; Roberts et al., 2009; Hanz et al., 2019). The role of internal waves (i.e. waves that occur at the interface between two water masses of different densities) on the proliferation of CWCs is important, since these oscillations increase turbulence and hence nutrient supply (White et al., 2005; Davies et al., 2009; Pomar et al., 2012; Wang et al., 2019). Physico-chemical properties of the ambient water (e.g. salinity, temperature, dissolved oxygen concentrations, pH, density) also affect CWC growth (Freiwald et al., 2004; Dullo et al., 2008; Davies and Guinotte, 2011; Hanz et al., 2019). If favourable conditions are maintained over longer periods, successive reef generations build CWC mounds through the interaction between coral growth and sediment accumulation (Wilson, 1979; Roberts et al., 2006; Foubert and Henriet, 2009; Roberts et al., 2009). Consequently, CWC mounds can reach considerable heights of over $300 \mathrm{~m}$ and spread for kilometres in width and length at their base (De Mol et al., 2002; Kenyon et al., 2003; Huvenne et al., 2005). Mound development may span from thousands to millions of years and attain important mound aggradation rates, e.g $290 \mathrm{~cm} \cdot \mathrm{ky}^{-1}$ in the Porcupine Seabight (Frank et al., 2009; López Correa et al., 2012; Stalder et al., 2015; Wienberg et al., 2018). As such, CWC mounds are valuable environmental and climatic archives, although mound formation is generally discontinuous (Rüggeberg et al., 2007; Roberts et al., 2009). Moreover, the sensitivity of CWCs to climate change renders them useful to monitor variations in environmental conditions (e.g., water mass variability, surface productivity, bottom current velocity; Rüggeberg et al., 2007; Huvenne et al., 2009; Hebbeln et al., 2016; Wienberg et al., 2018).

The long-term development of CWC mounds was first studied in the Northeast Atlantic Ocean, where it is recognized to be driven by large-scale changes in oceanographic conditions (e.g. Dorschel et al., 2005; Frank et al., 2011, Wienberg et al., 2018). Corals along the Irish margin grow during interglacial and interstadial times, whilst their development declines during glacial periods (Dorschel et al., 2005; Kano et al., 2007; Rüggeberg et al., 2007; Eisele et al., 2008). Cold-water coral mound development along the Irish margin depends on the strength of the Mediterranean Outflow Water (MOW) and the influence of internal waves (Mohn et al., 2014; Raddatz et al., 2014; Hebbeln et al., 2016). The strong influence of MOW during interglacial and interstadial times and the resulting enhanced turbulence induced by internal waves provides the correct balance between nutrient and sediment supply (Mohn et al., 2014; Raddatz et al., 2014). In contrast, during glacial times, weak MOW flow lowers nutrient supply and increases sediment smothering, causing coral retreat (Dorschel et al., 2005; Rüggeberg et al., 2007; Mohn et al., 2014). In the Northwest Atlantic Ocean, CWC mounds also form during interglacial periods, when stronger hydrodynamic regimes and better-oxygenated waters dominate the region (Matos et al., 2015; 2017). At lower latitudes in the East Atlantic, off the coast of Mauritania and in the Gulf of Cádiz, coral mounds form essentially 
during glacial times (Wienberg et al., 2009; Eisele et al., 2011), although they also developed at lower aggradation rates during the last interglacial (Marine Isotope Stage 5; Wienberg et al. 2018).

In the Mediterranean Sea, CWC mound provinces are mostly concentrated in the Alboran Sea, along the Moroccan margin (Fink et al., 2013; 2015; Lo Iacono et al., 2014; Stalder et al., 2015; 2018; Terhzaz et al., 2018; Wang et al., 2019; Rachid et al., 2020). The largest CWC mound field in this region is the Melilla Mound Field, covering an area greater than $500 \mathrm{~km}^{2}$ parallel to the margin (Comas and Pinheiro, 2010; Lo Iacono et al., 2014). It is divided into two provinces, the West and East Melilla Coral Provinces, respectively situated $7 \mathrm{~km}$ northwest and $35 \mathrm{~km}$ northeast of the Cape Tres Forcas (Hebbeln, 2019; Fig. 1). Several recent studies suggest an environmental forcing on CWC mound formation during the last $30 \mathrm{ky}$ at the Melilla mounds (Fink et al., 2013; Stalder et al., 2015; 2018; Wang et al., 2019; Feenstra, 2020). Mound aggradation rates reach their highest values (75-420 cm.ky ${ }^{-1}$ ) during the Early Holocene and Bølling-Allerød interstadial. In contrast, mound formation halted during the Younger-Dryas, demonstrating low mound aggradation rates (30-50 cm.ky ${ }^{-1}$; Fink et al., 2013; Stalder et al., 2015; Wang et al., 2019; Feenstra, 2020). Based on benthic foraminiferal assemblages, Stalder et al. (2015) suggest that cold/dense well oxygenated bottom water conditions favoured CWC development, whilst Wang et al. (2019) relate the intensified coral proliferation to high surface productivity combined with strong turbulence induced by internal waves.

Although the development of the East Melilla mounds during the last $30 \mathrm{ky}$ is well documented, the long-term development and environmental forcing affecting these mounds remain unknown. The aims of this study are: 1) to constrain the influence of climate variability on mound formation in the East Melilla region over the last $300 \mathrm{ky}$, and 2) to assess long-term coral mound formation in the area and compare it to North Atlantic counterparts.

\section{Study area}

\subsection{Geological setting}

The Alboran domain is structurally complex and its geodynamics are still debated (Duggen et al. 2008). Extension and subsidence occurred during the Early to Middle Miocene (Comas et al., 1999; Faccenna et al., 2004; Do Couto et al., 2016). As a result of the extension in the area, the Alboran Sea oceanic crust has been thinned, with a minimum thickness of $13 \mathrm{~km}$ in some parts (López Casado et al., 2001). The Alboran Sea is the westernmost basin of the Mediterranean Sea, and is closely connected to the Atlantic Ocean by the Strait of Gibraltar. The Alboran Sea is approximately $400 \mathrm{~km}$ long, with a width of $200 \mathrm{~km}$, an average depth of $1300 \mathrm{~m}$ and a maximum depth of $1800 \mathrm{~m}$ (Olivet et al., 1973; Comas et al., 1999). The Alboran Sea's metamorphic basement is intruded by a number of volcanic plateaus and seamounts formed through the extensional processes that took place between 17 and 8 million years ago (Comas et al., 1999; Duggen et al., 2008). One of these shallow volcanic plateaus, the Banc des Provençaux (ca. $200 \mathrm{~m}$ depth), extends in a series of 3 ridges colonized by CWCs, named "Brittlestar ridges" (BRI, BRII, BRIII) (Comas et al., 2009). They are part of the larger East Melilla Coral Province nestled at depths of between 250 and $450 \mathrm{~m}$. The ridges are 3 to $20 \mathrm{~km}$ in length, whilst the mounds vary in height from 50 to $150 \mathrm{~m}$ 
(Hebbeln et al., 2019). These mounds have mostly dead corals with scarce living corals at their summits and erosional moats at their base, supporting the presence of dynamic currents that influenced the area (Hebbeln et al., 2019) (Fig.1).

\subsection{Oceanography}

Low salinity (ca. 36.5 psu), low density Atlantic Water enters the Mediterranean through the Strait of Gibraltar. This inflowing water mass mixes with Mediterranean water while crossing the Strait of Gibraltar to form the Modified Atlantic Water (MAW), the dominant surface water mass in the Alboran Sea (La Violette, 1983; Millot, 2009). In addition, evaporation also exceeds river runoff and precipitation; hence MAW becomes saltier and denser journeying east and finally sinks in the Levantine, Aegean, Adriatic and Liguro-Provençal sub-basins (Millot et al., 2006). Intermediate waters consist of the highly saline (ca. 38.5 psu) and warm (ca. $13.5^{\circ} \mathrm{C}$ ) Levantine Intermediate Water (LIW) that forms in the Levantine basin and flows from East to West, entering the western Mediterranean through the Straits of Sicily to finally exit through the Strait of Gibraltar (Millot, 2013). Levantine Intermediate Water contributes to ca. $70 \%$ of the total outflow of Mediterranean Outflow Water (MOW; Millot, 2013). The LIW flows between 200 and $600 \mathrm{~m}$ water depth, whilst the core of the LIW is situated at approximately $400 \mathrm{~m}$ depth (Millot, 2009).

It is important to note that the LIW receives contributions from other intermediate water masses before it enters the western Mediterranean and hence has different characteristics to the LIW in the eastern Mediterranean (Millot, 2013). Moreover, intermediate waters appear to differ between the North and South Alboran Sea (Fig. 2). The LIW flows essentially along the Spanish margin, whilst Shelf Water (ShW), i.e. a mixture of MAW and Western Mediterranean Deep Water (WMDW), dominates intermediate depths along the Moroccan margin (Ercilla et al., 2016). Brittlestar Ridge I lies in the depth range of the ShW (Fig. 2). The deepest water mass, flowing under LIW and ShW, is WMDW, which forms in the Gulf of Lions and flows westward to finally exit through the Strait of Gibraltar and contribute to MOW (Millot et al., 2006). In the Alboran Sea, WMDW circulates principally along the Moroccan margin (Hernandez-Molina et al., 2002; Ercilla et al., 2016).

The surface MAW extends down to approximately 200 m depth (Katz, 1972) and enters the Northeast Alboran Sea as a jet (1.6 Sv; $1 \mathrm{~Sv}=10^{6} \cdot \mathrm{m}^{3} . \mathrm{s}^{-1}$; Lanoix, 1974). This jet triggers the formation of the quasi-permanent anti-cyclonic Western Alboran Gyre that contributes to mixing between surface MAW and underlying LIW (Heburn and La Violette, 1990; Lafuente et al., 1998). When the waters of the Western Alboran Gyre reach the African coast, they separate into two branches: one flows back westward along the coast towards the Strait of Gibraltar while the other flows towards the eastern part of the basin to form the Eastern Alboran Gyre (La Violette, 1983; Viúdez and Tintoré, 1995). This second non-permanent gyre also contributes to the mixing process between surface and intermediate water masses. The Banc des Provençaux and Brittlestar Ridge I are situated in the path of the eastward circulating branch/Eastern Alboran Gyre (Lanoix, 1974; Viúdez and Tintoré, 1995; Fig. 1). The mixing between surface and intermediate water masses occurs down to ca. $300 \mathrm{~m}$ water depth (Heburn and La Violette, 1990). The Strait of 
Gibraltar is a shallow (ca. $300 \mathrm{~m}$ depth) and narrow (ca. $20 \mathrm{~km}$ wide) crossing point for entering lower salinity MAW and exiting higher salinity MOW (Heburn and La Violette, 1990; Millot, 2009). Thus, the Strait of Gibraltar plays a key role in controlling water mass exchanges between the semi-enclosed Mediterranean Sea and the Atlantic Ocean. The importance of the water exchange varies between glacial and interglacial periods as a function of sea level change. Moreover, the narrow width and depth of the Strait of Gibraltar, together with the geometry of the Alboran basin and the Coriolis force, affects the formation, mean position and shape of the Alboran gyres (Heburn and La Violette, 1990). Thus, this will in turn affect mixing between surface and intermediate water masses in the Alboran Sea.

\section{Material and methods}

\subsection{Sample collection}

This study is based on the multiproxy analysis of gravity core MD13-3462G $\left(35^{\circ} 26.5311^{\prime} \mathrm{N}, 2^{\circ} 31.073^{\prime} \mathrm{W} ; 327 \mathrm{~m}\right.$ depth; $926 \mathrm{~cm}$ long) recovered during the EUROFLEETS cruise MD194 Gateway 'The Mediterranean-Atlantic Gateway Code: The Late Pleistocene Carbonate Mound Record' on board of the R/V Marion-Dufresne II (Van Rooij et al., 2013). Cores were split frozen and sedimentary facies descriptions were made at the University of Fribourg prior to sampling. These descriptions include the detailed investigation of texture, grain-size and colour of the matrix sediment, together with the identification and assessment of the preservation state of major macrofaunal components (Fig. 3). All data was plotted using the ggplot2 package for R (Wickham, 2016; R Core Team, 2018).

\subsection{Macrofaunal quantification}

X-ray Computed Tomography (CT) imaging was carried out on whole-round sections using a Siemens Somatom Definition AS64 at the Institute of Forensic Sciences at the University of Bern (Switzerland). Core sections were scanned using an X-ray source operating at $120 \mathrm{kV}$. The images were reconstructed with a slice thickness of $0.6 \mathrm{~mm}$ taking into account an increment of $0.3 \mathrm{~mm}$. The pixel resolution of the slices is $0.3 \mathrm{~mm}$. The Avizo 9.4 software was used to visualize, segment and quantify the volumes of the main macrofaunal components (coral, bryozoan and bivalve/brachiopod fragments). Prior to segmentation, images were filtered to remove noise in the matrix, using a non-local means filter. Brachiopods and bivalves were segmented manually. Corals, matrix, pores and bryozoans were segmented through the combination of dual thresholding and watershed segmentation. Labelled fragments smaller than 5 voxels were filtered prior to quantification. The material statistics module was used to quantify the volume $\%$ of faunal fragments per slice and the same volume of interest was selected for each core section.

\subsection{Geochemical logging}

Geochemical logging was performed using the Itrax high-resolution X-ray fluorescence (XRF) core scanner on split cores at the Institute of Geological Sciences, University of Bern (Switzerland). Measurements were taken at $5 \mathrm{~mm}$ intervals using an integration time of $20 \mathrm{~s}$ at $30 \mathrm{kV}$ and $45 \mathrm{~mA}$. To counter potentially biased measurements linked to 
the uneven surface of CWC cores, such as the direct measurement of air or of CWC skeletons, a post treatment of the dataset was carried out. X-ray fluorescence values with Argon counts higher than 6000, representing the measurement of air and thereby more porous/cracked media not representative for changes in sediment composition, were removed from the final dataset. In this study, we use the $\log _{10}$ normalized ratios (Gregory et al., 2019) Ti/Al and $\mathrm{Si} / \mathrm{Al}$ as proxies for aeolian input, whilst the $\log _{10} \mathrm{Zr} / \mathrm{Al}$ and $\mathrm{Rb} / \mathrm{Al}$ are used as proxies for fluvial input. Indeed, titanium enrichment is considered a typical indicator of increased Saharan dust influence (Frigola et al., 2008; Itambi et al., 2009; Rodrigo-Gámiz et al., 2011), as aeolian deposits tend to concentrate heavy minerals that are rich in elements such as titanium or zirconium (Balsam et al., 1995; Itambi et al., 2009, Rodrigo-Gamíz et al., 2011). Silicates make up an important part of Saharan material, whilst they are rare in Alboran sediments (Caquineau et al., 2002; Masqué et al., 2003). Thus, in the same way as for titanium, enrichment in silica can be used as a proxy for increased aeolian input originating from the Sahara (Rodrigo-Gámiz et al., 2011; Feenstra, 2020). Since rubidium is common in aluminosilicate minerals contained in fluvial material, the $\mathrm{Rb} / \mathrm{Al}$ ratio is used as an indicator of terrestrial run-off in the western Mediterranean (Calvert and Pedersen, 2007; Martinez-Ruiz et al., 2015; Feenstra, 2020). Though zirconium is generally considered as a proxy for aeolian input for the same reasons as Titanium (RodrigoGámiz et al., 2011), it has been shown that sediments originating from major Moroccan rivers are considerably enriched in zirconium (Stanley et al., 1975). We hence use the $\mathrm{Zr} / \mathrm{Al}$ and $\mathrm{Rb} / \mathrm{Al}$ ratios as regional proxies for fluvial input.

\subsection{Grain-size analysis and organic geochemistry}

Grain-size of the siliciclastic fraction was analysed using the Malvern Mastersizer 3000 at the Department of Geology, Ghent University (Belgium). The core was sampled with a small spoon $\left(1 \mathrm{~cm}^{3}\right)$ every $5 \mathrm{~cm}$. Large clasts $(>1 \mathrm{~cm})$, such as coral or bryozoan fragments, were removed prior to analysis. Samples were placed in $35 \% \mathrm{H}_{2} \mathrm{O}_{2}$ to remove organic matter and boiled until the reaction ended. Following this first step, samples were boiled in $10 \%$ $\mathrm{HCl}$ for 2 minutes to dissolve $\mathrm{CaCO}_{3}$. Prior to measurement, samples were placed in $2 \%$ sodium polymetaphosphate and boiled to assure complete disaggregation. Any remaining particle larger than $2 \mathrm{~mm}$ was sieved out before measurement. Eighty seven size classes were measured (from 0.01 to $2000 \mu \mathrm{m}$ ). Each sample was measured three times and results were then averaged. Mean grain-size of the siliciclastic fraction $\overline{G S}$ (Folk and Ward, 1957) was calculated on the entire dataset with the Rysgran package for R (Gilbert et al., 2015; R Core Team, 2018). The sortable silt mean size $\overline{S S}$, as defined by McCave et al. (1995; i.e. the mean of the 10-63 $\mu \mathrm{m}$ grain size range), was also calculated following the same procedure. Furthermore, following McCave and Hall (2006), the percentage of sortable silt (SS\%) in the total $<63 \mu \mathrm{m}$ fraction was calculated. This percentage, together with the sortable silt mean size, was used as a proxy for bottom current velocity (McCave and Hall, 2006; Toucanne et al., 2012). It has to be mentioned that the use of $\overline{S S}$ as a proxy for bottom current velocity on cores recovered from CWC mounds may be biased (e.g. Eisele et al., 2011). Indeed, the baffling effect of coral framework can locally reduce bottom current velocity and favour the deposition of fine sediments (Huvenne et al., 2009; Titschack et al., 2009; Fentimen et al., 2020), thus leading to an underestimation of $\overline{S S}$ during periods with high CWC content. Because of this, only relative increases in $\overline{S S}$ are considered in combination with results obtained from other proxies. 
Total Organic Carbon (TOC, weight\%) and Mineral Carbon (MinC, weight $\%$ ) contents were determined on matrix sediments every $10 \mathrm{~cm}$ using the Rock-Eval6 technique at the laboratory of Sediment Geochemistry at the University of Lausanne (Fantasia et al., 2019). Following Jiang et al. (2017), the percentage of carbonates was calculated as $\mathrm{CaCO}_{3}(\%)=7.976 \times$ MinC. The RockEval6 technique produces an Oxygen and Hydrogen index, respectively corresponding to the quantity of $\mathrm{CO}_{2}$ relative to TOC and the quantity of pyrolyzable organic compounds relative to TOC (Fantasia et al., 2019). These two indices give an indication about the origin of the organic matter present in the samples (Van Krevelen, 1993).

\subsection{Microfaunal and macrofaunal investigations}

The core was sampled (sliced) every $10 \mathrm{~cm}$ for micropalaeontological analysis. Samples were weighed dry, washed through a $63 \mu \mathrm{m}$ mesh sieve and dried at $30{ }^{\circ} \mathrm{C}$. Each fraction was then dry sieved through a series of 63,125 and $2000 \mu \mathrm{m}$ mesh sieves and weighed. A target number of 300 benthic foraminifera were identified from the fraction larger than $125 \mu \mathrm{m}$ for each sample. If the residue contained more than 300 specimens, it was split using a dry microsplitter. Relative abundances (percentages) of benthic species were calculated from the total benthic foraminiferal assemblage. The benthic foraminiferal density was calculated by dividing the total number of foraminifera of a given sample by the sample fraction's weight. The diversity Shannon index (H') was computed using the PRIMER6 software (Clarke and Gorley, 2006).

Samples prepared for micropaleontological analysis were further used to identify bryozoan species/genera at the Department of Biological, Geological and Environmental Sciences, University of Catania (Italy) on the $125 \mu \mathrm{m}$ to 2 $\mathrm{mm}$ and $>2 \mathrm{~mm}$ sized fractions. Key intervals with high bryozoan content, previously identified by CT imagery, were selected. Dominant scleractinian corals and main brachiopod and bivalve species were identified at the lowest taxonomic level possible on the $2 \mathrm{~mm}$ sized fraction at the Department of Geosciences, University of Fribourg (Switzerland).

\subsection{Oxygen and Carbon stable isotope analysis}

Stable oxygen and carbon isotope compositions were measured on 5 to 12 specimens of the planktonic foraminifera Globigerina bulloides and the benthic foraminifera Cibicides lobatulus from the size fraction 212-250 $\mu \mathrm{m}$ in order to prevent any ontogenic effect on the measurements (Schiebel and Hemleben, 2017). The specimens were first cleaned three times with distilled water in an ultrasonic bath for 2 seconds. The measurements were then made using a Thermo Fisher Scientific GasBench II connected to a Thermo Finnigan Delta Plus XL isotope ratio mass spectrometer at the Stable Isotope Laboratory of the University of Lausanne (Switzerland) according to the method adapted from Spötl and Vennemann (2003). Results are reported in the conventional $\delta$-values in permil (\%) relative to the Vienna Pee Dee Belemnite (VPDB) standard. Analytical standard deviations $(1 \sigma)$ average $0.04 \%$ for $\delta^{13} \mathrm{C}$ and $0.06 \%$ for $\delta^{18} \mathrm{O}$ values based on 8 replicate analyses of standards in each sequence of 40 samples. 


\subsection{Radiometric dating}

Radiocarbon dating was performed on benthic foraminifera from 3 samples from the upper first meter of core MD133462G at the Laboratory of Ion Beam Physics, ETH Zürich, Switzerland (Table 1). The epibenthic foraminifera species Discanomalina coronata, Cibicides lobatulus and Cibicides refulgens were picked in order to obtain between 4 and $10 \mathrm{mg}$ of pure carbonate. The samples were first dissolved in phosphoric acid. The resulting extracted $\mathrm{CO}_{2} \mathrm{Was}$ then converted to graphite and measured by Accelerator Mass Spectrometry (AMS) technique using the MICADAS dedicated instrument (Synal et al., 2007). Results were corrected for ${ }^{13} \mathrm{C}$ and calibrated using the Marine13 calibration curve (Reimer et al., 2013) and the software OxCal v4.2.4 (Ramsey, 2017). A reservoir age of $390 \pm 80$ years was applied to all ages (Siani et al., 2000).

Uranium-series dating was carried out on $10 \mathrm{CWC}$ fragments (D. pertusum and M. oculata) using a multicollector inductively coupled plasma source mass spectrometer MC-ICPMS (Thermo Fisher Scientific Neptune $e^{\text {plus }}$ ) coupled with a dissolver (Aridus I) at the Institute of Environmental Physics, Heidelberg University (Table 2). In order to constrain the chronostratigraphy of the core, well-preserved coral fragments were selected at the upper and lower boundaries of coral-rich units. These were identified based on visual core descriptions and CT-analysis (macrofaunal quantification; Fig. 3). Coral fragments were physically cleaned with a Dremel $^{\circledR}$ drill tool and by sand blasting, and further chemically cleaned using a weak acid leaching prior to measurements. The detailed sample protocol is described by Frank et al. (2004), while spectrometry and chemical U and Th extraction and purification followed Wefing et al. (2017). Uranium-series coral ages were used to calculate mound aggradation rates.

\section{Results}

\subsection{Chronostratigraphy}

The chronostratigraphy of core MD13-3462G is based on the combination of the coral ages (U-series dating), the planktonic and benthic stable oxygen isotope records, and the foraminiferal radiocarbon ages for the top first meter of the core (Fig. 3). Coral ages have been widely used to define the chronology of cores recovered from coral mounds. This approach provides satisfying results although age reversals down core have to be taken into account (e.g. Rüggeberg et al., 2007; Frank et al., 2009; Matos et al., 2017). Indeed, reefs are fragile structures and can collapse, topple and fragment through the action of bioerosion, strong bottom currents, and gravity-driven processes, resulting in transport and redeposition of coral fragments (Beuck et al., 2005; Dorschel et al., 2007; White et al., 2007). In contrast, constructing a continuous age model based on stable isotope records is generally considered untrustworthy for cores collected from coral mounds since sedimentation is intermittent (Dorschel et al., 2005). However, coral ages at the upper and lower boundaries of coral build-up phases in core MD13-3462G (e.g. at 390 and $507 \mathrm{~cm}$ depth) correspond to changes in the stable oxygen isotope records (Fig. 3), which in turn match the changes between Marine Isotope Stages (MIS; Lisiecki and Raymo, 2005). As such, the stable oxygen isotope records can, in the case of core MD13-3462G and in conjunction with coral ages, indicate important stratigraphic 
boundaries (Fig. 3). This is particularly relevant during times when CWCs did not grow and hence cannot serve to construct a timeframe.

The coral ages indicate that core MD13-3462G extends approximately from $300 \mathrm{ka}$ BP (Marine Isotope Stage 9) to the Holocene (Fig. 3, Table 2). The stratigraphic boundaries from the base of the core to ca. $600 \mathrm{~cm}$ depth were defined based on the coral ages as planktonic stable oxygen isotope compositions show little variation. The boundaries of MIS 8 are the most poorly defined (Fig. 3). Due to difficulties to define precisely the stratigraphy of this section of the core, it will not be considered in detail during this study. In contrast, the planktonic and benthic $\delta^{18} \mathrm{O}$ values and the coral ages do constrain the stratigraphic boundaries from MIS 6 to MIS 1 (Fig. 3). Low planktonic and benthic $\delta^{18} \mathrm{O}$ values correspond to interglacial periods, whilst high planktonic and benthic $\delta^{18} \mathrm{O}$ values correspond to the last glacial periods of MIS 6, 2 and 2 (Fig. 3). These boundaries are confirmed by the coral and foraminiferal ages (Fig. 3; Tables 1 and 2). Highest planktonic and benthic $\delta^{18} \mathrm{O}$ values (3.5 and $4 \%$ ) correspond to MIS 4 whilst average planktonic and benthic $\delta^{18} \mathrm{O}$ values between 2 and $3 \%$ correspond to MIS 3 .

\subsection{Sediment characterization}

The sediment in core MD13-3462G consists mostly of macrofaunal remains (essentially corals and bryozoans) surrounded by a clay- to silt-sized carbonate/siliciclastic matrix. No important variation in the matrix sediment is observed throughout the core. Carbonate content varies from ca. 10 to $86 \%$, whilst average values generally range between 40 and $60 \%$ (Fig. 4). Total organic carbon content in the sediment varies between 0.16 and 1.13 wt\% (Fig. 4). The highest TOC value is measured during late MIS 3 (1.13 wt \%), whilst the lowest is recorded during MIS 8 (0.16 wt\%; Fig. 4). The most important shifts to higher TOC values are observed during MIS 5, MIS 3 and at the transition between MIS 2 and MIS 1 (Fig. 4). High TOC values correspond to interglacials, whilst low values correspond to glacials (Fig. 4). The sediment samples are further characterized by high Oxygen index values (> 200 $\mathrm{mg} \mathrm{CO} / \mathrm{g}$ TOC; Supplementary data), indicating that the organic matter is oxidized and of essentially terrestrial origin (Espitalié et al., 1985).

The mean grain size of the siliciclastic fraction $(\overline{G S})$ varies between ca. 6 and $14 \mu \mathrm{m}$ (Fig. 4), whilst $\overline{S S}$ varies between ca. 19 and ca. $26 \mu \mathrm{m}$ (Fig. 4). Trends in $\overline{S S}$ follow those of $\overline{G S}$ (Fig. 4). Overall, a decrease in $\overline{S S}$ and $\overline{G S}$ is associated to intervals marking the transitions from interglacial to glacial periods (Fig. 4). Conversely, an increasing trend is observed from ca. 550 to ca. $375 \mathrm{~cm}$ depth, corresponding to the passage from the later phases of MIS 6 to the end of MIS 5 (Fig. 4). This trend is mirrored in $\overline{G S}$ (Fig. 4). A sharp decrease in $\overline{S S}$ and $\overline{G S}$ marks the passage from MIS 3 to MIS 2 and the later phase of MIS 2 (Fig. 4). The percentage of sortable silt (SS\%) increases with $\overline{S S}$ (Fig. 5). As discussed by McCave and Hall (2006) and McCave et al. (2017), the straight-line relationship (slope of ca. $0.125 \mu \mathrm{m} / \%$ and an intercept at $0 \%$ of ca. $17.5 \mu \mathrm{m}$ ) between $\overline{S S}$ and SS\% is indicative of a sorting process induced by bottom currents (Fig. 5). 


\subsection{Macrofauna}

The major macrofaunal fragments present in the core are scleractinian corals, bryozoans, brachiopods and bivalves (Fig. 3; Fig. 6). Sea urchins, gastropods, serpulids and gorgonian fragments are more sporadically distributed. The dominant coral species in the core is the scleractinian D. pertusum. In the upper $20 \mathrm{~cm}, D$. pertusum is replaced by M. oculata (Fig. 3; Fig. 6). A third and solitary species, Desmophyllum dianthus, is scarcely distributed (Fig. 3). High CWC content is observed during interglacial periods, whilst low content characterizes glacial periods (Fig. 3). During MIS 3 coral content shows a more staggered distribution, with a range of values from less than 10 vol\% to ca. 27 vol\% (Fig. 3).

In total 23 genera of bryozoans were identified. Buskea dichotoma is by far the dominant bryozoan species (Fig. 6). Accessory species/genera are mainly represented by Reteporella sparteli, Tubuliporina sp. and Palmiskenea sp. Bryozoan content varies in general between 10 and 20 vol\% (Fig. 3). Very high content is, however, observed during MIS 2, reaching near to 70 vol\%. The fragments, although delicate and fragile, are well preserved, large sized and unworn (Fig. 6). Bryozoans are absent during most of MIS 5. This absence corresponds to the interval when coral content is the most important (Fig. 3). Conversely, the maximum abundance of bryozoans during MIS 2 correlates to a minimum in coral content (Fig. 3).

Brachiopods are mainly represented by the co-occurrence of the species Gryphus vitreus and Terebratulina retusa (Fig. 6). These two brachiopods are regularly associated to the bivalve Bathyarca pectunculoides (Fig. 6). These three inverterbrates have been formerly reported from Mediterranean CWC environments. Gryphus vitreus and Terebratulina retusa are also recorded from Pleistocene CWC deposits from Rhodes, Greece (Bromley, 2005), whilst Bathyarca pectunculoides was found at the Santa Maria di Leuca CWC province (Mastrototaro et al., 2010; Negri and Corselli, 2016). Gryphus vitreus was also found associated to "white corals" between 235 and $255 \mathrm{~m}$ depth off the coast of the Hyères Islands, France (Emig and Arnaud, 1988). Although being fragile, the shells are well preserved (Fig. 6). The brachiopod/bivalves concentrate as layers; hence they demonstrate a non-continuous distribution (Fig. 3 and 6). They reach their highest abundance during glacial periods, in particular at the end of MIS $3(30 \mathrm{vol} \%$ at $80 \mathrm{~cm}$ ). Brachiopods and bivalves are completely absent during the last two interglacial periods (Fig. $3)$.

\subsection{Benthic foraminiferal assemblages}

Shannon diversity ranges between ca. 2.8 at $652 \mathrm{~cm}$ and 3.6 at $782 \mathrm{~cm}$ (Fig. 7). High Shannon diversity values between 3.4 and 3.6 are recorded during interglacial periods (Fig. 7). The lowest Shannon diversity values (between 2.8 and 3.0) are associated to glacial periods (Fig. 7). A total number of 166 benthic foraminifera species were recognized (Annex 1). The most abundant species are Bolivina spathulata, Bulimina marginata, Bulimina striata, Cassidulina laevigata, Cibicides lobatulus, Discanomalina coronata, Gavelinopsis praegeri, Globocassidulina subglobosa, Hyalinea balthica, Miliolinella subrotunda, Trifarina angulosa and Uvigerina mediterranea. 
The three Buliminid species B. aculeata, B. marginata and B. striata demonstrate the same distribution trends and were thus grouped together as Bulimina spp. All Miliolids were grouped together for the same reason. The species M. subrotunda makes up more than half of the total abundance of the Miliolid group with an average contribution of ca. $53.4 \%$. The abundances of all important species are given in Figure 7. The opportunistic infaunal Bulimina spp. show maximum abundances during interglacial periods (ca. $18 \%$ ) and minimum abundances during glacial periods (ca. $2 \%$; Fig. 7). Uvigerina mediterranea follows a similar distribution to Buliminids, with peak abundances corresponding to interglacial periods (Fig. 7). Relative to Bulimina spp., U. mediterranea, G. subglobosa and B. spathulata, the infaunal T. angulosa and the epifaunal D. coronata are the least abundant during the last two interglacials (between ca. 1 and $5 \%$ ), whilst they are the most abundant during glacial periods, with peak abundances reached during MIS 4 for D. coronata (ca. $30 \%$; Fig. 7). Abundances of Miliolids (5-22\%), C. lobatulus (3-17\%) and C. laevigata (3-17\%) are relatively high throughout the entire core (Fig. 7); although Miliolids show higher abundances during glacials (ca. $20 \%$ ). The highest numbers of $C$. laevigata are recorded during glacial periods (ca. $20 \%$ ), whilst minimum abundances occur during interglacials (3\% during MIS 5). The epifaunal G. praegeri is homogeneously distributed, in contrast to $H$. balthica that first appears in the core at the onset of MIS 5, reaching maximum abundances during MIS 2 (ca. $11 \%$; Fig. 7).

\subsection{Stable carbon isotopes}

The range of $\delta^{13} \mathrm{C}$ values of the planktonic G. bulloides is between $-2.2 \%$ at $12 \mathrm{~cm}$ and $-0.5 \%$ at $292 \mathrm{~cm}$, whereas that for the benthic C. lobatulus is between $0.9 \%$ at $872 \mathrm{~cm}$ and $1.8 \%$ at $362 \mathrm{~cm}$ (Fig. 4). The planktonic $\delta^{13} \mathrm{C}$ record has more variability compared to the benthic $\delta^{13} \mathrm{C}$ record (Fig. 4). During MIS 6, the benthic $\delta^{13} \mathrm{C}$ is relatively high (ca. $1.5 \%$ ), whilst the planktonic $\delta^{13} \mathrm{C}$ record fluctuates between $-0.6 \%$ and $-1.5 \%$. A decrease in the planktonic $\delta^{13} \mathrm{C}$ record (from -0.7 to $-1.5 \%$ ) marks the middle of MIS 5. In contrast, the benthic $\delta^{13} \mathrm{C}$ remains stable and low (ca. $1.2 \%$ ) throughout MIS 5 (Fig. 4). The passage from MIS 4 to MIS 3 is characterized by a shift from the low planktonic $\delta^{13} \mathrm{C}$ recorded during MIS $4\left(-1.5 \%\right.$ ) to higher planktonic $\delta^{13} \mathrm{C}(-0.5 \%)$. Conversely, benthic $\delta^{13} \mathrm{C}$ values shift from high $(1.8 \%)$ to lower values $(1.3 \%)$. The passage from MIS 2 to MIS 1 is marked by a sharp decrease in planktonic and benthic $\delta^{13} \mathrm{C}$ (from $-1.2 \%$ to $-2.2 \%$ and from $1.8 \%$ to $1.0 \%$ respectively). The last two glacial intervals, in particular MIS 4 , are marked by a stronger difference between benthic and planktonic $\delta^{13} \mathrm{C}$ values (Fig. 4).

\subsection{Elemental geochemistry}

The $\mathrm{Ti} / \mathrm{Al}$ and $\mathrm{Si} / \mathrm{Al}$ ratios follow the same general trend. Variations in Ti/Al and $\mathrm{Si} / \mathrm{Al}$ ratios are more marked during MIS 7 and MIS 3, in comparison with the more stable values recorded during other periods. Maximum average $\mathrm{Ti} / \mathrm{Al}$ and $\mathrm{Si} / \mathrm{Al}$ values are reached during glacials, whereas interglacials record the lowest values (Fig. 8). $\mathrm{The} \mathrm{Zr} / \mathrm{Al}$ and $\mathrm{Rb} / \mathrm{Al}$ ratios follow the same trend, whilst differing strongly from the Ti/Al and Si/Al records. The $\mathrm{Zr} / \mathrm{Al}$ and $\mathrm{Rb} / \mathrm{Al}$ ratios demonstrate overall low values throughout the core. However, higher $\mathrm{Zr} / \mathrm{Al}$ and $\mathrm{Rb} / \mathrm{Al}$ ratios are reached at the end of MIS 6, and during MIS $5(\mathrm{ca} .400 \mathrm{~cm}$ ) and MIS $3(\mathrm{ca} .100 \mathrm{~cm})$. In the same way as for 
$\mathrm{Ti} / \mathrm{Al}$ and $\mathrm{Si} / \mathrm{Al}$ records, $\mathrm{Zr} / \mathrm{Al}$ and $\mathrm{Rb} / \mathrm{Al}$ ratios demonstrate an important variability during $\mathrm{MIS} 3$, in comparison to other periods where the records are comparatively stable (Fig. 8).

\section{Discussion}

\subsection{Environmental controls on coral proliferation during interglacial periods}

\subsubsection{Humid continental conditions, fluvial discharge and increased food availability}

During interglacial periods, benthic foraminiferal assemblages are marked by high abundances of the infaunal

Bulimina spp., U. mediterranea and B. spathulata. Several authors describe Bulimina spp. as characteristic for eutrophic and dysoxic environments (Phleger and Soutar, 1973; Lutze and Coulbourn, 1984; Jorissen, 1987; Schmiedl et al., 2000). In the Mediterranean Sea, they are dominant in the vicinity of the Po river delta in the North Adriatic Sea and close to the Rhône River delta (Jorissen, 1987; Mojtahid et al., 2009). The shallow infaunal $U$. mediterranea and the opportunistic B. spathulata are known to demonstrate a positive correlation with organic matter flux (De Rijk et al., 2000; Schmiedl et al., 2000; Fontanier et al., 2002; 2003; Drinia and Dermitzakis, 2010). Moreover, Bulimina spp. and U. mediterranea are reported to be able to feed on fresh but also more refractory organic matter (De Rijk et al., 2000; Koho et al., 2008; Dessandier et al., 2016). Based on these observations, the benthic foraminiferal assemblage during interglacials would support a high organic matter export to the seafloor. The overall higher TOC levels during interglacials confirm that the sediment during these periods was relatively enriched in organic matter in comparison to glacial periods (Fig. 4). High abundance of the shallow infaunal G. subglobosa has been linked to the deposition of fresh phytodetritus on the seafloor after bloom events (Gooday, 1993; Fariduddin and Loubere, 1997; Suhr et al., 2003; Sun et al., 2006). It is typically found in high energy (e.g. steep flanks, ridges) and well-oxygenated environments (Mackensen et al., 1995; Milker et al., 2009), and is a common taxon of the Alboran Platform and of CWC environments (Margreth et al., 2009; Milker et al., 2009; Spezzaferri et al., 2014). Mackensen et al. (1995) noted that G. subglobosa dominated in areas of the South Atlantic Ocean where the organic carbon flux did not exceed $1 \mathrm{~g} \mathrm{~cm}^{-2} \mathrm{yr}^{-1}$. In contrast, in the Mediterranean Sea, B. marginata is restricted

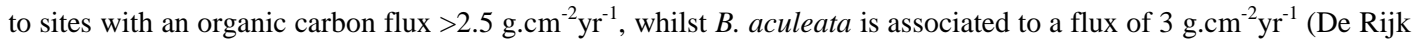
et al., 2000). The last two interglacials (MIS 7 and MIS 5) are marked by an increased abundance of G. subglobosa at early stages followed by a general decline. Buliminids follow a converse trend, particularly during MIS 5, with lower abundances at early stages (Fig. 7). This suggests that conditions during the later stages of interglacials became increasingly eutrophic and in turn less oxygenated at the sediment/water interface, as the consumption of organic matter led to oxygen depletion. These more environmentally stressful conditions resulted in decreased foraminiferal diversity and a proliferation of opportunistic taxa (Fig. 7). Overall lower abundances of Miliolids, which are typically found in well-oxygenated environments (Murray, 2006), further confirm eutrophication coupled to lower oxygenation at the seafloor during interglacials, specifically towards the end of interglacials (Fig. 7). 
Schmiedl et al. (2010) link the high abundance of $U$. mediterranea in the Aegean Sea to humid climatic conditions and increased river runoff. This observation is in agreement with overall increased fluvial and reduced aeolian input during interglacial periods at BRI, as evidenced by the Al-normalized elemental ratios (Fig. 8). Increased fluvial input has been widely linked in the eastern Mediterranean to more humid continental conditions during interglacial times in response to a northern shift of the African monsoon (e.g. Gasse, 2000; Gasse and Roberts, 2005; Osborne et al., 2008; Coulthard et al., 2013). In contrast, the Alboran Sea lies below the maximum Inter-Tropical Convergence Zone northward position and is sheltered by the Atlas Mountain chain (Rohling et al., 2002; Tuenter et al., 2003; Lavaysse et al., 2009). Modern-day observations show that rainfall over the northwest Atlas Mountains is generally associated to baroclinic activity over the North Atlantic (Knippertz et al., 2003; Braun et al., 2019). The south of the Atlas Mountains has one of the highest cyclonic activities in the Mediterranean borderlands, whilst the largest fraction of cyclones entering the Mediterranean Sea arrives from the Atlantic (Lionello et al., 2016). Pasquier et al. (2018) noticed that periods of increased input of organic matter from sediment-laden rivers occur during warm substages of the last $200 \mathrm{ky}$. These authors relate these pluvial events to negative North Atlantic Oscillation-like conditions (Pasquier et al., 2018). The East Melilla Coral Province is located $50 \mathrm{~km}$ away from the mouth of the Moulouya River which takes its source in the High Atlas Mountains (Snousi, 2004; Emelyanov and Shimkus, 2012; Tekken and Kropp, 2012). The basin of the Moulouya River covers approximately 54,000 $\mathrm{km}^{2}$, hence representing the largest river basin in Northwest Africa (Emelyanov and Shimkus, 2012; Tekken and Kropp, 2012). We propose that the influence of warm and moist Atlantic air masses during interglacial periods led to warmer and more humid conditions over Northwest Africa and torrential rain fall. This would have led to a strengthening of the Moulouya River's flow rate, hence triggering episodes of important terrestrial organic matter input at BRI. These events may have in turn caused eutrophication and oxygen depletion at the seafloor, compatible with the benthic foraminiferal assemblages. Dysoxic conditions during interglacial periods would have hampered coral proliferation, as suggested by the low mound aggradation rates (Fig. 9). However, dysoxic conditions may have been limited to the sediment, thus only affecting foraminiferal communities and not fully preventing colonial corals living above the sediment surface to develop. Such vertical decoupling between sediment and pelagic ecosystems has previously been observed in modern Norwegian CWC reefs (Wehrmann et al., 2009). Overall, high food availability triggered by increased fluvial discharge appears to be a decisive parameter governing coral proliferation at BRI.

\subsubsection{Enhanced surface and intermediate water mass mixing}

During interglacial periods, the high sea level and the increased evaporation in the Mediterranean leads to a more important inflow of low salinity MAW through the Strait of Gibraltar (Sierro et al., 2005). Thus, surface waters in the Alboran Sea are, in comparison to glacial periods, warmer and less dense. This is also noticed in the planktonic $\delta^{18} \mathrm{O}$ record (Fig. 3). The enhanced MAW flow during interglacials triggers stronger Western and Eastern Alboran 450 Gyres, resulting in better mixing and downwelling. Knowing that the Banc des Provençaux and BRI are situated at relatively shallow water depths and in the path of the eastward circulating branch/Eastern Alboran Gyre (Lanoix, 1974; Viúdez and Tintoré, 1995; Fig. 10), and that mixing between surface and intermediate water masses is 
documented to occur down to ca. $300 \mathrm{~m}$ water depth (Heburn and La Violette, 1990), it is conceivable that the corals living currently at $327 \mathrm{~m}$ depth were bathed by, or situated at the limit of mixing between surface and intermediate water masses during interglacial periods. Higher input of MAW into the Alboran Sea would lead to an increased contribution of surface waters to intermediate water masses (ShW) and a deepening of the pycnocline. This would promote the formation of internal waves and increase turbulence at the seafloor of BRI, as suggested by the slightly higher $\overline{S S}$ values during interglacials (Fig. 4 and 5), and would have favoured coral proliferation by increasing lateral nutrient supply (Fig. 10). The slight offset between planktonic and benthic $\delta^{13} \mathrm{C}$ records towards the end of MIS 7 and MIS 5 indicate that water masses were becoming more stratified towards the end of interglacials and that the contribution of MAW to intermediate water masses was hence possibly decreasing. Maximum Bulimina spp. abundance, minimum $G$. subglobosa abundance, and decreasing benthic foraminiferal diversity may suggest that reduced mixing, in concomitance with important fluvial discharge (section 6.1.1) led to oxygen depletion at the seafloor at the transition between interglacial and glacial periods. Severe oxygen depletion may explain the decline of corals at the transition from interglacial to glacial periods.

\subsubsection{Variability of cold-water coral mound formation between interglacial periods}

Highest coral content is reached during MIS 5 and corresponds to a maximum in Buliminid abundance. The Alnormalized elemental ratios suggest that aeolian input during MIS 5 was relatively stable, whilst fluvial input would have increased throughout (Fig. 8). These stable conditions would have favoured a long-lasting coral proliferation dominated by the scleractinian D. pertusum (Fig. 3). Marine Isotope Stage 9 and 7 are also dominated by $D$. pertusum. Although MIS 7 is poorly constrained, Al-normalized elemental ratios would indicate that this time period was more unstable than the previous interglacial period (Fig. 8). The late Holocene is marked by a decrease in coral abundance and a dominance of $M$. oculata over D. pertusum. The coral fragment at the top of core MD13-3462G has an age of $6.3 \mathrm{ka}$. Fink et al. (2013) obtained ages from surface coral fragments at BRI that were generally between 2.7 and $3.1 \mathrm{ka}$, whilst Stalder et al. (2015) reported an age of $5.4 \mathrm{ka}$ for a surface coral fragment sampled at BRI. Similar ages of between 3.5 and $5.8 \mathrm{ka}$ were obtained on surface coral fragments at the Western Melilla Coral Province (Wang et al. 2019). Dominance of the coral M. oculata during the Late Holocene was also observed at BRI by Stalder et al. (2015), whilst Wienberg (2019) reported that $M$. oculata already became the dominant coral species during the mid-Holocene. Previous observations suggest that $M$. oculata is more tolerant to environmental stress than D. pertusum (e.g. Wienberg et al., 2009; Stalder et al., 2015). Thus, the dominance of $M$. oculata at the top of the core would indicate that conditions during the late Holocene were becoming increasingly unsuitable for coral proliferation, particularly for $D$. pertusum. This is consistent with modern-day seafloor observations that report a near-absence of CWCs at BRI (Hebbeln et al., 2019). These combined results point to unfavourable conditions for coral proliferation during the late Holocene, as suggested by Fink et al. (2013), Stalder et al. (2015; 2018) and Wang et al. (2019). The recent decline of CWCs at the Eastern and Western Melilla Coral Provinces may be linked to the establishment of more arid conditions over North Africa ca. 4 ka ago (Gasse, 2000 and references therein; Shanahan et al., 2015). The fluctuations in coral and bryozoan abundances between the different interglacial periods may be caused by the influence of alternating dry and humid conditions. 


\subsection{Environmental conditions during glacial periods}

\subsubsection{Arid continental conditions and reduced bottom currents}

At the exception of MIS 8, for which the boundaries are poorly defined, glacial periods are marked by a change in macrofaunal composition with lower coral and higher bryozoan content in comparison to interglacial periods. Higher bryozoan content during glacials at BRI is in tune with observations made at the Great Australian Bight, where lower temperatures, lower sea level stand, and increased upwelling probably promoted bryozoan proliferation during glacial periods (James et al., 2000; Holbourn et al., 2002). Conversely, higher temperatures and downwelling during interglacials halted bryozoan extension at the Great Australian Bight (James et al., 2000; Holbourn et al., 2002). Rigid erect branching bryozoans such as $B$. dichotoma are known to be fragile, and hence to prefer low energy environments, being unable to withstand strong bottom currents and turbulence (Scholz and Hillmer, 1995; Bjerager and Surlyk, 2007). Eutrophic environments dominated by infaunal benthic foraminifera (e.g. Bulimina spp.) are unfavourable for erect bryozoans, the high concentration of suspended food particles clogging up their feeding apparatus (Holbourn et al., 2002). Low $\overline{S S}$ values and reduced TOC content in the sediment confirm that glacial periods were marked by weak bottom current velocities and organic matter flux (Fig. 4 and 5). The presence of brachiopod/bivalve layers dominated by the brachiopod Gryphus vitreus also characterizes the glacial macrofauna (Fig. 3). This species is found between 160 and $250 \mathrm{~m}$ depth along the Mediterranean continental margin and thrives in areas dominated by moderate bottom currents (Emig and Arnaud, 1988). Thus, this species' co-occurrence with bryozoans confirms that variations in sea level stand, hydrodynamics and trophic conditions govern the change in macrofaunal dominance at BRI. Low organic matter flux during glacial periods has been related to predominantly arid conditions over North Africa, in association with a weak North African monsoon (Gasse, 2000; Sierro et al., 2005). Such arid conditions led to the complete or severe desiccation of major African lakes during the last glacial, such as Lake Victoria (Talbot and Livingstone, 1989; Johnson, 1996). High Ti/Al and Si/Al elemental ratios would indicate that aeolian input prevailed during glacial periods at BRI (at the exception of MIS 3, section 6.4), hence confirming that continental conditions were arid at these times (Fig. 8 and 9).

The reduced precipitation and retreat of vegetation would have led to a dwindling of fluvial discharge at BRI, as evidenced by generally low $\mathrm{Zr} / \mathrm{Al}$ and $\mathrm{Rb} / \mathrm{Al}$ elemental ratios (Fig. 8). Glacial benthic foraminiferal assemblages are characterized by the dominance of large epibenthic suspension feeding foraminifera, such as C. lobatulus and $D$. coronata, together with the infaunal C. laevigata (Fig. 7). This follows observations made by Stalder et al. (2018) who noticed increased abundances of Cibicides spp., D. coronata and C. laevigata during glacial periods at BRI. These species share a preference for high quality fresh marine organic matter (De Rijk et al., 2000; Milker et al., 2009, Stalder et al., 2018). Cibicides lobatulus and D. coronata prefer oxygen-rich bottom waters (Linke and Lutze; 1993; Margreth et al., 2009), whilst following Milker et al. (2009), high abundances of C. laevigata could be related to the presence of fine grained material in the western Mediterranean. Increased abundance of C. laevigata matches minimum $\overline{G S}$ values, thus confirming this species' affinity for fine grained glacial material (Fig. 4). In the Arctic basins and Norwegian-Greenland Sea, the dominance of the epibenthic Cibicides wuellerstorfi (a relative of $C$. 

rates $<2 \mathrm{~g} . \mathrm{cm}^{-2} \cdot \mathrm{yr}^{-1}$ (Altenbach, 1989). The dominance of C. lobatulus, D. coronata, C. laevigata and Miliolids would thus indicate that the seafloor during glacial periods received less but higher quality organic matter and became more oxygenated in response to the stronger influence of intermediate and deep water masses (Fig. 10). These observations suggest that more arid conditions during glacial periods led to a shift from a more fluvial to a more marine influenced environment (Fig. 10). We propose that weaker but comparatively fresher organic matter input favoured the development of the bryozoan B. dichotoma. This assumption is supported by experimental observations demonstrating how erect bryozoans feed essentially on diatoms and that suspension feeding foraminifera use the same food sources (Winston, 1977; 1981; Best and Thorpe, 1994; Goldstein, 1999). Lower nutrient input appears in contrast to have been detrimental for coral proliferation but would not have led to their complete disappearance (Fig. 3 and 10). It can be hypothesized that there may exist a threshold in the quality and quantity of organic matter determining which of D. pertusum or B. dichotoma dominates the benthic environment at BRI.

\subsubsection{Increased stratification and deep water overturning}

As highlighted previously, the dominant macrofauna and low $\overline{S S}$ values (Fig. 3, 4 and 5) during glacial intervals at

BRI indicate weaker bottom currents. Wang et al. (2019) relate low off mound $\overline{G S}$ and high benthic foraminiferal $\delta^{13} \mathrm{C}$ values at BRI during glacials to a dominant influence of MAW coinciding with a low sea level stand. However, whilst the benthic foraminiferal $\delta^{13} \mathrm{C}$ values from core $\mathrm{MD13}-3462 \mathrm{G}$ are indeed relatively high during glacial periods, the planktonic foraminiferal $\delta^{13} \mathrm{C}$ values do not follow the same trend (Fig. 4). The decoupling between the planktonic and benthic $\delta^{13} \mathrm{C}$ records during the two last glacial periods, noticeably during MIS 4, suggests that water mass stratification was greater than during interglacial periods and that the seafloor was not under the direct influence of surface MAW. During glacial periods, the flow of MAW was reduced due to lower sea level and the reduced evaporation over the Mediterranean (Sierro et al., 2005). This would have reduced the contribution of MAW to ShW and weakened Western and Eastern Alboran Gyres, which would have in turn led to less mixing between surface and intermediate water masses, whilst conversely increasing stratification.

Modern observations show that recently formed dense waters do not necessarily reach the deep western Mediterranean but may, in contrast, be located at intermediate water depths, above $1500 \mathrm{~m}$ depth (Sparnocchia et al., 1995; Millot, 1999; Ercilla et al., 2016). Ercilla et al. (2016) further exposed that WMDW can be identified at depths shallower than $500 \mathrm{~m}$ depth along the Moroccan margin and that it contributes to the overlying ShW, whilst deep water overturning and ventilation peaked during MIS 2 (Cacho et al., 2006; Toucanne et al., 2012). Increased oxygenation of the seafloor, as evidenced by the benthic foraminiferal assemblage (Fig. 7), may suggest that the contribution of well-ventilated deep and intermediate water masses at BRI was more important during glacials than during interglacials (Fig. 10). The physical shape of BRI possibly plays a role in the rise of deep waters during glacial periods. In addition, the heavier benthic $\mathrm{C}$-isotope record and the abundance of fresh organic matter feeding foraminifera (C. lobatulus and D. coronata) during glacial periods could indicate that these waters were also 
nutrient-rich. Although stratification between surface and intermediate water masses was greater during glacials, the stronger flow of well-ventilated WMDW at BRI would explain the higher oxygen availability at the seafloor. Overall during glacial periods, and in particular during the LGM, enhanced contribution of nutrient-rich and well-ventilated WDMW to overlying ShW, coupled to reduced fluvial input and turbulence, would have promoted bryozoan proliferation (Fig. 10). However, such environmental conditions would be detrimental for coral proliferation (Fig. $10)$.

\subsubsection{Fluctuating environmental conditions during the last glacial period}

The benthic and planktonic foraminifera $\delta^{18} \mathrm{O}$ and $\delta^{13} \mathrm{C}$ values indicate that environmental conditions were particularly unstable during the last glacial period, as suggested by previous studies (Cacho et al., 2000; Martrat et al., 2004; Pérez-Folgado et al., 2004; Cacho et al., 2006; Bout-Roumazeilles et al., 2007). The last glacial shows a strong variability in macrofaunal and benthic foraminiferal assemblages. Maximum coral content is reached during MIS 3 (Fig. 3). This increased coral content is associated to higher numbers of G. subglobosa and C. laevigata, together with phases of higher $\mathrm{Zr} / \mathrm{Al}$ and $\mathrm{Rb} / \mathrm{Al}$ elemental ratios (Fig. 7 and 8). These observations suggest that corals and the benthic foraminiferal community positively responded to short phases of increased surface productivity related to important continental runoff during MIS 3. This is supported by observations made by Rogerson et al. (2018), who documented more humid conditions during MIS 3 in comparison to the more arid MIS 4 and 2. Humid conditions would hence have promoted coral proliferation through increased fluvial input at BRI, in the same way as during interglacial periods (section 6.1). Nevertheless, the dominance of G. subglobosa coupled to the absence of Bulimina spp. and $U$. mediterranea suggests that conditions were less eutrophic than during peak interglacial periods and that the organic matter reaching the seafloor may have been less degraded.

At BRI, high planktonic foraminiferal $\delta^{18} \mathrm{O}$ values during the last glacial are associated with increased Ti/Al and $\mathrm{Si} / \mathrm{Al}$ elemental ratios (Fig. 8). There is evidence that during times of increased aridity, enhanced African winds blew north towards the Alboran Sea (Magri and Parra, 2002; Bout-Roumazeilles et al., 2007). During Heinrich Event 1, the existence of a steppe/semi-desertic flora around the Alboran borderlands points to cold and dry climatic conditions (Combourieu Nebout et al. 2009). The association of high Ti/Al and Si/Al ratios with high planktonic foraminiferal $\delta^{18} \mathrm{O}$ values confirms that increased aridity on land coupled to strong winds were concomitant with lower sea surface temperatures at BRI (Fig. 8). The arid continental conditions during these particularly cold spells would have led to reduced continental runoff. This could in turn explain the overall dwindling of coral communities during these cold events (Fig. 3). Cacho et al. (1999) and Martrat et al. (2004) showed that sea surface temperature minima matched higher planktonic G. bulloides $\delta^{18} \mathrm{O}$ values in the Alboran Sea during the last glacial. Moreover, these sea surface temperature minima are concurrent with North Atlantic Heinrich Events, i.e. the deposition of icerafted detritus from massive iceberg discharges during some of the colder stadials (Heinrich, 1988; Bond et al., 1992). Ice-rafted detritus layers were observed as far south as the Portuguese margin (Lebreiro et al., 1996; Bard et al., 2000; Schönfeld and Zahn, 2000), the Gulf of Cádiz (Llave et al., 2006; Toucanne et al., 2007) and the Moroccan margin (Kudras and Thiede, 1970). Rapidly decreasing sea surface temperatures were also associated to North 
Atlantic Heinrich events of the Bermuda Rise (Sachs and Lehman, 1999) and in the Alboran Sea (Cacho et al., 1999). Moreover, based on palynological and mineralogical evidence, Bout-Roumazeilles et al. (2007) revealed an intensification of wind, dust erosion and transport toward the Alboran Sea in provenance of western Morocco during North Atlantic cold events. Based on these observations, we tentatively suggest that the dwindling of coral communities during the last glacial period may also be linked to the inflow of Atlantic glacial freshwater during Atlantic cold events. More precise investigations are however needed to assert this relationship.

\subsection{Interglacial-glacial transition phases}

The western Mediterranean is marked by abrupt interglacial-glacial transitions (Martrat et al. 2004). Benthic foraminiferal assemblages and $\overline{S S}$ would confirm that the environment at BRI also experienced such abrupt transitions. Indeed, the interglacial-glacial transitions are characterized by increased $\overline{S S}$ values and T. angulosa abundances (Fig. 3 and 7). Trifarina angulosa is typical for current-swept areas and can withstand permanent winnowing (Mackensen et al., 1995; Schönfeld, 2002; Margreth et al., 2009). These results suggest that transition phases between interglacial and glacial periods were characterized by winnowing at the seafloor. In contrast, benthic foraminiferal assemblages and $\overline{S S}$ would indicate that transition phases from glacial to interglacial periods were not marked by winnowing or erosional events. These observations differ from the ones drawn from Northeast Atlantic mounds, where winnowing and mass wasting are considered as precursor events for the re-initiation of coral proliferation during interglacials (Dorschel et al., 2005; Rüggeberg et al., 2007). Thus, the environmental mechanisms triggering the reset of coral proliferation at the onset of interglacials at BRI appear to be different from the Northeast Atlantic. The re-establishment of coral proliferation during the last two interglacials at BRI is concomitant with an increase in Buliminid abundance. This increase in Buliminid abundance is coupled to higher $\mathrm{Rb} / \mathrm{Al}$ values at the transition between MIS 6 and 5 (Fig. 7, 8). These observations confirm that the recovery of coral proliferation at BRI is tightly linked to an increase in river runoff, which in turn reflects more humid continental conditions. A similar process has been reported from the Viosca Knoll area, where the dispersal of terrestrial organic matter by the Mississippi River triggers an increase in primary productivity, providing nutrients for coral communities (Mienis et al., 2012). As such, water mass rearrangements appear to be of secondary importance, whilst the rapid increase in fluvial discharge would be the primary factor triggering coral proliferation at BRI.

\subsection{Differences between Southeast Alboran and North Atlantic coral mound formation}

\subsubsection{Coral proliferation and environmental forcing}

In the Northeast and Northwest Atlantic, corals thrive during interglacial periods whilst their proliferation is halted during glacial periods (Dorschel et al., 2005; Rüggeberg et al., 2007; Frank et al., 2009; 2011; Matos et al., 2015; 2017). Coral proliferation at BRI does not follow the same pattern. Indeed corals also develop during interglacial periods, but also to a lesser extent during glacial periods (Fig. 3). Coral proliferation in the Northeast Atlantic is controlled by the northward advance of subtropical waters and of MOW (Henry et al., 2014; Boavida et al., 2019), whereas corals at BRI are influenced by the interplay between inflowing MAW and outflowing LIW, ShW and 
WMDW (Stalder et al., 2015; 2018; Wang et al., 2019; this study). Environmental control on coral development in both regions shares similarities but also shows differences. The positive response of corals to increased bottom current velocity is important in both regions. This follows the general consensus that strong bottom currents are decisive for the development of corals (e.g. White et al., 2005; Mienis et al., 2007; Roberts et al., 2009). The topography of Brittlestar Ridge I may favour the formation of Taylor columns and the retention of organic matter, such as observed in the Rockall Trough (Northeast Atlantic, White et al., 2007). However, benthic foraminiferal assemblages associated to phases of coral proliferation in the Northeast Atlantic (Rüggeberg et al., 2007) and in the Southeast Alboran Sea (this study) differ. Benthic foraminiferal assemblages associated to phases of sustained coral proliferation at Propeller Mound (Northeast Atlantic) are essentially characterized by large epibenthic foraminifera (C. lobatulus, Cibicides refulgens, D. coronata, and Planulina ariminensis) and the infaunal Trifarina bradyi (Rüggeberg et al., 2007). In contrast, at BRI, higher abundances of C. lobatulus, D. coronata and T. angulosa are associated to glacial periods or transition phases between interglacial and glacial periods with low coral abundance, while small infaunal foraminifera dominate phases of coral proliferation (Fig. 7). These contrasting observations suggest differences in food supply and bottom current regimes. Corals in the Northeast Atlantic thrive on fresh marine-derived organic matter resulting from the North Atlantic blooms which are fuelled by upwelling (Dickinson et al., 1980). In contrast, corals at BRI are likely supplied by plankton blooms triggered by the input of degraded fluvial organic matter during interglacial times, whilst aeolian dust input allows corals to survive during glacial times by triggering local moderate bloom events in the area. In this regard, coral mounds situated in the Southeast Alboran Sea show more similarities to mounds located in the Viosca Knoll area or in the Gulf of Cadiz (Wienberg et al., 2010; Mienis et al., 2012). The respective shallow location and proximity of BRI to the continent explains the higher influence of continental runoff on coral communities than in the deeper Northeast Atlantic sites. It can hence be expected that corals at BRI show higher sensibility to shifting continental climatic conditions.

\subsubsection{Long-term coral mound build-up}

Average mound aggradation rates for core MD13-3462G are particularly low in comparison to other CWC mound provinces (Frank et al., 2011; Wienberg and Titschak, 2015). A maximum rate of ca. $9 \mathrm{~cm} . \mathrm{ky}^{-1}$ is reached during MIS 4, whilst rates do not exceed ca. $4 \mathrm{~cm}^{\mathrm{ky}}{ }^{-1}$ during interglacial periods (Fig. 9). In comparison, mound aggradation rates during the Early Holocene reached up to $869 \mathrm{~cm} \cdot \mathrm{ky}^{-1}$ at Stjernsund Fjord (Norwegian margin) and 290 cm.ky ${ }^{-1}$ in the Porcupine Seabight (López Correa et al., 2012; Frank et al., 2009; Wienberg and Titschak, 2015). Moreover, mound aggradation rates during the Holocene for core MD13-3462G (Fig. 9) are extremely low in comparison to other reported rates in the area. Indeed, Fink et al. (2013) and Stalder et al. (2015) report aggradation rates between ca. 260 and $290 \mathrm{~cm} . \mathrm{ky}^{-1}$ for the Early Holocene at the East Melilla Coral Province, whilst Wang et al. (2019) calculated rates between ca. 75 and $107 \mathrm{~cm} \cdot \mathrm{ky}^{-1}$ for the West Melilla Coral Province. These combined observations suggest that coral mound formation demonstrates strong spatial and temporal variability at the East Melilla Coral Province, and more precisely during the Holocene at BRI. 
Long-term coral mound formation at BRI and in the Porcupine Seabight do not show the same temporal distribution. Indeed, mound aggradation in the Porcupine Seabight is restricted to interglacial periods, whilst glacials are marked by winnowing and erosive events (Rüggeberg et al., 2007; Frank et al., 2011). Long-term coral mound formation at BRI took place during interglacial and glacial periods, though at much lower aggradation rates than in the Porcupine Seabight (Fig. 9; Frank et al., 2011). Mound aggradation rates in core MD13-3462G are comparable to inactive or abandoned reefs in the Porcupine Seabight, i.e. $<5 \mathrm{~cm}^{-k^{-1}}$ (Frank et al., 2011), thus suggesting that CWCs did not thrive at the site of core MD13-3462G but rather developed under stressful, possibly dysoxic, environmental conditions. Average long-term mound aggradation rates at BRI show more similarities with mounds situated along the Mauritanian margin that developed during the last glacial $\left(28-45 \mathrm{~cm} \cdot \mathrm{ky}^{-1}\right)$ but also during the last interglacial period (16 cm.ky ${ }^{-1}$; Wienberg et al., 2018; Wienberg and Titschak, 2015). In contrast with Atlantic CWC mounds, mounds from the East Melilla Coral Province show a high contribution of the erect cheleistome bryozoan $B$. dichotoma. Based on mound aggradation rates and macrofaunal content, we propose that $B$. dichotoma communities favoured mound formation at BRI, noticeably during glacial periods, by capturing fine-grained sediments in a similar way as CWCs do (Fig. 3 and 9). As such, mounds at BRI stand out and may be considered as mixed $B$. dichotoma/CWC mounds, rather than CWC mounds per se.

\section{Conclusions}

The multiproxy study of core MD13-3462G provides information on the long-term development of a cold-water coral mound at Brittlestar Ridge I. Three important points can be concluded:

(1) Cold-water corals develop mainly during interglacial periods. Their growth is promoted by the combination of increased fluvial input and enhanced influence of Alboran Gyres. Increased fluvial organic matter inputs are driven by the increased impact of warm and moist Atlantic air masses with intensified Western and Eastern Alboran Gyres that lead to more important turnover between surface and intermediate water masses. This phenomenon is promoted by enhanced Modified Atlantic Water inflow at the Strait of Gibraltar. The seafloor was possibly depleted in oxygen at the end of interglacial phases. These results demonstrate the paramount importance of enhanced fluvial input as a trigger for cold-water growth in the Southeastern Alboran Sea.

(2) Glacial periods are unfavourable for cold-water corals; in contrast the bryozoan Buskea dichotoma is more suited to glacial environmental conditions. The retreat of corals during glacial periods is triggered by arid continental conditions that lead to reduced fluvial input and nutrient supply. Moreover, reduced inflow of Modified Atlantic Water at the Strait of Gibraltar results in a lower contribution of surface waters to intermediate waters. In contrast, the contribution of Western Mediterranean Deep Water to intermediate water masses increased. Weaker Alboran Gyres and increased contribution of well-ventilated deep waters at intermediate depths resulted in increased stratification. Lower input of organic matter, but less degraded, further characterizes glacial environmental 

periods.

(3) Average coral mound aggradation rates are particularly low, varying between 1 and $9 \mathrm{~cm} . \mathrm{ky}^{-1}$. Mound formation takes place during glacial periods as well as during interglacial periods. Low mound aggradation rates during interglacials and glacials suggest that corals did not thrive but rather developed under stressful environmental conditions at Brittlestar Ridge I. The erect cheleistome bryozoan Buskea dichotoma plays an important role in the long-term mound formation at Brittlestar Ridge I, noticeably during glacial periods. Overall, mound development at Brittlestar Ridge I is controlled by alternating aeolian and fluvial inputs, in response to North Atlantic climate dynamics.

From a wider perspective, this study demonstrates how cold-water coral environments can benefit from both fluvial and aeolian terrestrial input, during respectively interglacial and glacial periods. These results underline how coldwater coral systems are capable of withstanding important environmental changes and to survive and adapt to different climatic conditions.

\section{Data availability}

All the datasets used in this study are available at the open-access repository PANGEA (data awaiting DOI and link).

\section{Sample availability}

Archive halves of all core sections investigated for this study are available at the Department of Geosciences, University of Fribourg (Switzerland). The sediment residues and the splits of each sample analysed for benthic foraminiferal assemblages are stored at the Department of Geosciences, University of Fribourg (Switzerland). Bryozoans identified in this study are available at the Palaeontological Museum of the University of Catania (Italy).

\section{Author contributions}

RF: writing (original draft), visualization, conceptualization, core sampling, investigation (benthic foraminiferal assemblages, main macrofaunal fragments, particle size analysis, stable isotope measurements assisted by TV and radiocarbon dating assisted by $\mathrm{IH}$ ). EF: conceptualization, writing (review and editing), XRF investigation (assisted by HV), preparation of samples for Uranium-series dating and RockEval6 pyrolysis. ARu: conceptualization, writing (review and editing), supervision. EH: investigation (CT analysis, macrofaunal quantification). VR: writing (review and editing), visualization. TV: writing (review and editing), investigation (stable isotope measurements), resources. IH: writing (review and editing), investigation (radiocarbon dating), resources. ARo: writing (review and editing), investigation (bryozoan taxonomy). DVR: writing (review and editing), resources. TA: writing (review and editing), 
investigation (RockEval6 pyrolysis), resources. HV: writing (review and editing), investigation (XRF), resources. NF \& TK: writing (review and editing), investigation (Uranium-series dating). AF: investigation (core description, CT data analysis, XRF data analysis), conceptualization, writing (review and editing), project administration, funding acquisition, supervision.

\section{Competing interests}

The authors declare that they have no conflict of interest.

\section{Acknowledgements}

We thank the SNSF (Swiss National Science Foundation) projects 'Unconventional Carbonate Factories' and '4DDiagenesis@Mound' (project numbers 200020_153125 and 200021_149247) for funding this research. We also are grateful for the ship time provided by IPEV on the R/V Marion Dufresne II within the framework of the EuroFLEETS GATEWAYS project (grant agreement 228344). We further thank Tim Collart for the help he provided with the Rysgran package for $\mathrm{R}$ and Marc Schori for his help with the ArcGIS software. We further acknowledge the help of Rene Eichstädter and Andrea Schröder-Ritzrau regarding Uranium-series dating and quality control. The DFG has provided funding for the Uranium-series dating of corals via the project FR1341/9-1.

\section{References}

Addamo, A.M., Vertino, A., Stolarski, J., García-Jiménez, R., Taviani, M., and Machordom, A.: Merging scleractinian genera: the overwhelming genetic similarity between solitary Desmophyllum and colonial Lophelia, BMC Evol Biol, 16, 108, 2016.

Altenbach, A.V. and Sarnthein, M.: Productivity Record in Benthic Foraminifera, in: Productivity of the Ocean: Present and Past, edited by: Berger, W.H., Smetacek, V.S., and Wefer, G., John Wiley \& Sons Limited, 255269, 1989.

Balsam, W.L., Otto-Bliesner, B., and Deaton, B.C.: Modern and last glacial maximum eolian sedimentation patterns in the Atlantic Ocean interpreted from sediment iron oxide content, Paleoceanography, 10, 493-507, 1995.

Bard, E., Rostek, F., Turon, J.-L., and Gendreau, S.: Hydrological Impact of Heinrich Events in the Subtropical Northeast Atlantic, Science, 289, 1321-1324, 2000.

Best, M.A. and Thorpe, J.P.: Particle size, clearance rate and feeding efficiency in marine Bryozoa, in: Biology and Palaeobiology of Bryozoans, edited by: Hayward, P.J., Ryland, J.S., and Taylor, P.D., Olsen and Olsen, Fredensborg, Denmark, 9-14, 1994.

Beuck, L. and Freiwald, A.: Bioerosion patterns in a deep-water Lophelia pertusa (Scleractinia) thicket (Propeller Mound, northern Porcupine Seabight), in: Cold-water corals and ecosystems, published by: Freiwald, A. and Roberts, J.M., Springer-Verlag, Berlin Heidelberg, 915-936, 2005. 
Bjerager, M. and Surlyk, F.: Benthic palaeoecology of Danian deep-shelf bryozoan mounds in the Danish Basin, Palaeogeogr Palaeocl, 250, 184-215, 2007.

Boavida, J.R., Becheler, R., Choquet, M., Frank, N., Bourillet, J-F., and Arnaud-Haond, S.: Out of the Mediterranean? Post-glacial colonisation pathways varied among cold-water coral species, J Biogeogr, 1-17, 2019.

Bond, G., Heinrich, H., Broecker, W., Labeyrie, L., McManus, J., Andrews, J., Huon, S., Jantschik, R., Clasen, S., Simet, C., Tedesco, K., Klas, M., Bonani, G., and Ivy, S.: Evidence for massive discharges of icebergs into the North Atlantic ocean during the last glacial period, Nature, 360, 245-249, 1992.

Bout-Roumazeilles, V., Combourieu Nebout, N., Peyron, O., Cortijo, E., Landais, A., and Masson-Delmotte, V.: Connection between South Mediterranean climate and North African atmospheric circulation during the last 50,000 yr BP North Atlantic cold events, Quaternary Sci Rev, 26, 3197-3215, 2007.

Braun, K., Nehme, C., Pickering, R., Rogerson, M., and Scroxton, N.: A window into Africa's past hydoclimates: the SISAL_V1 database contribution, Quaternary, 2, 4, 2019.

Bromley, R.G.: Preliminary study of bioerosion in the deep-water coral Lophelia, Pleistocene, Rhodes, Greece, in: Cold-water Corals and Ecosystems, edited by: Freiwald, A. and Roberts, J.M., Springer-Verlag, Berlin Heidelberg, 895-914, 2005.

Cacho, I., Grimalt, J.O., Pelejero, C., Canals, M., Sierro, F.J., Flores, J.A., and Shackleton, N.: Dansgaard-Oeschger and Heinrich event imprints in Alboran Sea paleotemperatures, Paleoceanography, 14, 698-705, 1999.

Cacho, I., Grimalt, J.O., Sierro, F.J., Scackleton, N.J., and Canals, M.: Evidence for enhanced Mediterranean thermohaline circulation during rapid climatic coolings, Earth Planet Sc Lett, 183, 417-429, 2000.

Cacho, I., Shackleton, N., Elderfield, H., Sierro, F.J., and Grimalt, J.O.: Glacial rapid variability in deep-water temperature and $\delta^{18} \mathrm{O}$ from the Western Mediterranean Sea, Quaternary Sci Rev, 25, 3294-3311, 2006.

Calvert, S.E. and Pedersen, T.F.: Elemental Proxies for Palaeoclimatic and Palaeoceanographic Variability in Marine Sediments: Interpretation and Application, in: Developments in Marine Geology, edited by Hillaire-Marcel, C. and De Vernal, A., Elsevier, 2007

Caquineau, S., Gaudichet, A., Gomes, L., and Legrand, M.: Mineralogy of Saharan dust transported over northwestern tropical Atlantic Ocean in relation to source regions, J Geophys Res-Atmos, 107, 1-14, 2002.

Carlier, A., Le Guilloux, E., Olu, K., Sarrazin, J., Mastrototaro, F., Taviani, M., and Clavier, J.: Trophic relationships in a deep Mediterranean cold-water coral bank (Santa Maria di Leuca, Ionian Sea). Mar Ecol Prog Ser, 397, 125-137, 2009.

Cheng, H., Adkins, J., Lawrence Edwards, R., and Boyle, E.A.: U-Th dating of deep-sea corals, Geochim Cosmochim Ac, 64, 14, 2401-2416, 2000.

Clarke, K.R. and Gorley, R.N.: PRIMER v6: User Manual/Tutorial (Plymouth Routines in Multivariate Ecological Research), PRIMER-E, Plymouth, 2006.

Comas, M.C., Platt, J.P., Soto, J.I. and Watts, A.B.: The origin and tectonic history of the Alboran Basin: insights from Leg 161 results, Proceedings of the Ocean Drilling Program 161, Scientific Results, 1999.

Comas, M., and Pinheiro, L.M.: The Melilla carbonate mounds: do deep-water coral mounds count on seeping fluids in the Alboran Sea? Rapp. Comm. Int. Mer Médit, 39, 16, 2010. 

climatic variability in the west Mediterranean during the last 25000 years from high resolution pollen data, Clim Past, 5, 503-521, 2009.

Coulthard, T.J., Ramirez, J.A., Barton, N., Rogerson, M., and Brucher, T.: Were rivers flowing across the Sahara during the last interglacial? Implications for human migration through Africa, PLoS One, 8, e74834. 2013.

Davies, A.J. and Guinotte, J.M.: Global habitat suitability for framework-forming cold-water corals, PLoS One 6, e18483, 2011.

Davies, A.J., Duineveld, G., Lavaleye, M., Bergman, M., van Haren, H., and Roberts, J.: Downwelling and deepwater bottom currents as food supply mechanisms to the cold-water coral Lophelia pertusa (Scleractinia) at the Mingulay Reef Complex, Limnol Oceanogr, 54, 620-629, 2009.

De Mol, B., Van Rensbergen, P., Pillen, S., Van Herreweghe, K., Van Rooij, D., McDonnell, A., Huvenne, V.A.I., Ivanov, M., Swennen, R., and Henriet, J.-P.: Large deep-water coral banks in the Porcupine Basin, southwest of Ireland, Mar Geol, 188, 193-231, 2002.

De Rijk, S., Jorissen, F., Rohling, E.J., and Troelstra, S.R.: Organic flux control on bathymetric zonation of Mediterranean benthic foraminifera, Mar Micropaleontol, 40, 151-166, 2000.

Dessandier, P.-A., Bonnin, J., Kim, J.-H., Bichon, S., Deflandre, B., Grémare, A., and Sinninghe Damsté, J.S.: Impact of organic matter source and quality on living benthic foraminiferal distribution on a river-dominated continental margin: A study of the Portuguese margin, J. Geophys. Res. Biogeosci., 121,1689-1714, 2016.

Dickinson, R.R., Gurbutt, P.A., and Pillai, V.N.: Satellite evidence of enhanced upwelling along the European continental slope, Geology, 813-819, 1980.

Do Couto, D., Gorini, C., Jolivet, L., Lebret, N., Augier, R., Gumiaux, C., d'Acremont, E., Ammar, A., Jabour, H., and Auxietre, J.-L.: Tectonic and stratigraphic evolution of the Western Alboran Sea Basin in the last 25 Myrs, Tectonophysics, 677-678, 280-311, 2016.

Dorschel, B., Hebbeln, D., Ruggeberg, A., Dullo, W-C, and Freiwald, A.: Growth and erosion of a cold-water coral covered carbonate mound in the Northeast Atlantic during the Late Pleistocene and Holocene, Earth Planet Sc Lett, 233, 33-44, 2005.

Dorschel, B., Hebbeln, D., Foubert, A., White, M., and Wheeler, A.J.: Hydrodynamics and cold-water coral facies distribution related to recent sedimentary processes at Galway Mound west of Ireland, Mar Geol, 244, 184-195, 2007.

Drinia, H. and Dermitzakis, M.D.: The response of benthic foraminifera to palaeoenvironmental disturbance: A quantitative approach in turbidite-like successions, N. Jb. Geol. Paläont. Abh, 258, 3, 325-338, 2010.

Duggen, S., Hoernle, K., Klügel, A., Geldmacher, J., Thirlwall, M., Hauff, F., Lowry, D., and Oates, N.: Geochemical zonation of the Miocene Alborán Basin volcanism (westernmost Mediterranean): geodynamic implications, Contrib Mineral Petr, 156, 577-593, 2008.

Dullo W-C., Flögel, S. and Rüggeberg, A.: Cold-water coral growth in relation to the hydrography of the Celtic and Nordic European continental margin, Mar Ecol Prog Ser, 371, 165-176, 2008.

Eisele, M., Hebbeln, D., and Wienberg, C.: Growth history of a cold-water coral covered carbonate mound Galway Mound, Porcupine Seabight, NE-Atlantic, Mar Geol, 253, 160-169, 2008. 
Eisele, M., Frank, N., Wienberg, C., Hebbeln, D., López Correa, M., Douville, E., and Freiwald, A.: Productivity controlled cold-water coral growth periods during the last glacial off Mauritania, Mar Geol, 280, 143-149, 2011.

Emelyanov, E.M. and Shimkus, K.M.: Geochemistry and sedimentology of the Mediterranean Sea, Springer Science and Business Media, 2012.

Emig, C.C. and Arnaud, P.M.: Observations en submersible sur la densité des populations de Gryphus vitreus (Brachiopode) le long de la marge continentale de Provence (Méditerranée nord-occidentale), C. R. Acad. Sci. Paris, 306, 501-505, 1988.

Ercilla, G., Juan, C., Hernández-Molina, J., Bruno, M., Estrada, F., Alonso, B., Casas, D., Farran, M., Llave, E., García, Vázquez, J.T., D’Acremont, E., Gorini, C., Palomino, D., Valencia, J., El Moumni, B., and Ammar, A.: Significance of bottom currents in deep-sea morphodynamics: An example from the Alboran Sea, Mar Geol, 378, 157-170, 2016.

Espitalié, J., Deroo, G., and Marquis, F.: La Pyrolyse Rock-Eval et ses applications, Revue de l'Institut Français du Pétrole, 40, 5, 1-34, 1986.

Faccenna, C., Piromallo, C., Crespo-Blanc, A., Jolivet, L., and Rossetti, F.: Lateral slab deformation and the origin of the western Mediterranean arcs, Tectonics, 23, 2004.

Fantasia, A., Adatte, T., Spangenberg, J.E., Font, E., Duarte, L.V., and Föllmi, K.B.: Global versus local processes during the Pliensbachian-Toarcian transition at the Peniche GSSP, Portugal: a multi-proxy record, Earth-Sci Rev, 198, 102932, 2019.

Fariduddin, M. and Loubere, P.: The surface ocean productivity response of deeper water benthic foraminifera in the Atlantic Ocean, Mar Micropaleontol, 32, 289-310, 1997.

Feenstra, E.J. Carbonate preservation pathways in cold-water coral mounds, PhD, University of Fribourg (Switzerland), 2020.

Fentimen, R., Lim, A., Rüggeberg, A., Wheeler, A.J., Van Rooij, D., and Foubert, A.: Impact of bottom water currents on benthic foraminiferal assemblages in a cold-water coral environment: The Moira Mounds (NE Atlantic), Mar. Micropaleontol, 154, 101799, 2020.

Fink, H.G., Wienberg, C., De Pol-Holz, R., Wintersteller, P., and Hebbeln, D.: Cold-water coral growth in the Alboran Sea related to high productivity during the Late Pleistocene and Holocene, Mar Geol, 339, 71-82, 2013.

Fink, H.G., Wienberg, C., De Pol-Holz, R., and Hebbeln, D.: Spatio-temporal distribution patterns of Mediterranean cold-water corals (Lophelia pertusa and Madrepora oculata) during the past 14,000 years, Deep-Sea Res Pt I, 103, 37-48, 2015.

Folk, R.L. and Ward, W.C.: A Study in the Significance of Grain-Size Parameters, J Sediment Petrol, 27, 3-26, 1957.

Fontanier, C., Jorissen, F.J., Licari, L., Alexandre, A., Anschutz, P., and Carbonel, P.: Live benthic foraminiferal faunas from the Bay of Biscay: faunal density, composition, and microhabitats, Deep-Sea Res Pt I, 49, 751-785, 2002.

Fontanier, C., Jorissen, F.J., Chaillou, G., David, C., Anschutz, P., and Lafon, V.: Seasonal and interannual variability of benthic foraminiferal faunas at 550m depth in the Bay of Biscay, Deep-Sea Res Pt I, 50, 457-494, 2003. 
Foubert, A. and Henriet, J.-P.: Nature and Significance of the Recent Carbonate Mound Record, Lecture Notes in Earth Sciences, 126, Springer-Verlag, Berlin, 298 pp., 2009.

Frank, N., Paterne, M., Ayliffe, L., van Weering, T., Henriet, J.-P., and Blamart, D.: Eastern North Atlantic deep-sea corals: tracing upper intermediate water $\Delta^{14} \mathrm{C}$ during the Holocene, Earth Planet Sc Lett, 219, 297-309, 2004.

Frank, N., Ricard, E., Lutringer-Paquet, A., van der Land, C., Colin, C., Blamart, D., Foubert, A., Van Rooij, D., Henriet, J.-P., de Haas, H., and van Weering, T.: The Holocene occurrence of cold water corals in the NE Atlantic: Implications for coral carbonate mound evolution, Mar Geol, 266, 129-142, 2009.

Frank, N., Freiwald, A., Correa, M.L., Wienberg, C., Eisele, M., Hebbeln, D., Van Rooij, D., Henriet, J.P., Colin, C., van Weering, T., de Haas, H., Buhl-Mortensen, P., Roberts, J.M., De Mol, B., Douville, E., Blamart, D., and Hatte, C.: Northeastern Atlantic cold-water coral reefs and climate, Geology, 39, 743-746, 2011.

Freiwald, A., Fosså, J.H., Grehan, A., Koslow, T., and Roberts, J.M.: Cold-water coral Reefs, UNEP_WCMC, Cambridge, UK, 2004.

Frigola, J., Moreno, A., Cacho, I., Canals, M., Sierro, F.J., Flores, J.A., and Grimalt, J.O.: Evidence of abrupt changes in Western Mediterranean Deep Water circulation during the last $50 \mathrm{ky}$ : A high resolution marine record from the Balearic Sea, Quatern Int, 181, 88-104, 2008.

Gasse, F.: Hydrological changes in the African tropics since the Last Glacial Maximum, Quaternary Sci Rev, 19, 189-211, 2000.

Gasse, F. and Roberts, C.N.: Late Quaternary hydrologic changes in the arid and semiarid belt of northern Africa, in: The Hadley Circulation: Present, Past and Future, edited by: Diaz, H.F. and Bradley, R.S., Kluwer Academic Publishers, 313-345, 2005.

Gilbert, E.R., Camargo, M.G. and Sandrini-Neto, L.: rysgran: Grain size analysis, textural classifications and distribution of unconsolidated sediments, $\mathrm{R}$ package version 2.1.0, $\underline{\text { https://CRAN.R- }}$ project.org/package=rysgran, 2015.

Goldstein S.T.: Foraminifera: A biological overview, in: Modern Foraminifera, edited by: Sen Gupta, B.K., 37- 55, Kluwer Acad., Norwell, Mass., 1999.

Gooday, A.J.: The Biology of Deep-Sea Foraminifera: A Review of Some Advances and Their Applications in Paleoceanography, Palaios, 9, 14-31, 1993.

Gregory, B.R.B., Patterson, T.R., Reinhardt, E.G., Galloway, J.M., and Roe, H.R.: An evaluation of methodologies for calibrating Itrax X-ray fluorescence counts with ICP-MS concentration data for discrete sediment samples, Chem Geol, 525, 12-27, 2019.

Hanz, U., Wienberg, C., Hebbeln, D., Duineveld, G., Lavaleye, M., Juva, K., Dullo, W.-C., Freiwald, A., Tamborrino, L., Reichart, G.-J., Flögel, S., and Mienis, F.: Environmental factors influencing cold-water coral ecosystems in the oxygen minimum zones on the Angolan and Namibian margins, Biogeosciences, 1-37, 2019.

Hebbeln, D., Van Rooij, D., and Wienberg, C.: Good neighbours shaped by vigorous currents: Cold-water coral mounds and contourites in the North Atlantic, Mar Geol, 378, 171-185, 2016.

Hebbeln, D.: Highly variable submarine landscapes in the Alborán Sea created by cold-water corals, in: Mediterranean Cold-Water Corals: Past, Present and Future, published by: Orejas, C. and Jiménez, C., Springer series: Coral Reefs of the World 9, Springer International Publishing, 61-65, 2019. 
Heburn, G.W. and La Violette, P.E.: Variations in the structure of the anticyclonic gyres found in the Alboran Sea, J Geophys Res, 95, 1990.

Heinrich, H.: Origin and Consequences of Cyclic Ice Rafting in the Northeast Atlantic Ocean during the Last 130,000 Years, Quaternary Res, 29, 142-152, 1988.

Henry, L.A., Frank, N., Hebbeln, D., Wienberg, C., Robinson, L., van de Flierdt, T., Dahl, M., Douarin, M., Morrison, C.L., Lopez Correa, M., Rogers, A.D., Ruckelshausen, M., and Roberts, J.M.: Global ocean conveyor lowers extinction risk in the deep sea, Deep-Sea Res Pt I, 88, 8-16, 2014.

Holbourn, A., Kuhnt, and W., James, N.: Late Pleistocene bryozoan reef mounds of the Great Australian Bight: Isotope stratigraphy and benthic foraminiferal record, Paleoceanography, 17, 2002.

Huvenne, V.A.I., De Haas, H., Dekindt, K., Henriet, J-P., Kozachenko, M., Olu-Le Roy, K., and Wheeler, A.J.: The seabed appearance of different coral bank provinces in the Porcupine Seabight, NE Atlantic: results from sidescan sonar and ROV seabed mapping, in: Cold-water Corals and Ecosystems, edited by: Freiwald, A. and Roberts, J.M., Springer-Verlag, Berlin, Heidelberg, 536-569, 2005.

Huvenne, V.A.I., Masson, D.G., and Wheeler, A.J.: Sediment dynamics of a sandy contourite: the sedimentary context of the Darwin cold-water coral mounds, Northern Rockall Trough, Int J Earth Sci98, 865-884, 2009.

Itambi, A.C., von Dobeneck, T., Mulitza, S., Bickert, T., and Heslop, D.: Millenial-scale northwest African droughts related to Heinich events and Dansgaard-Oeschger cycles: evidence in marine sediments offshore Senegal, Paleoceanography, 24, 1, PA1205, 2009.

Jaffey, A.H., Flynn, K.F., Glendenin, L.E., Bentley, W.C., and Essling, A.M.: Precision measurements of half-lives and specific activities of ${ }^{235} \mathrm{U}$ and ${ }^{238} \mathrm{U}$, Phys Rev, 4, 5, 1889-1906, 1971.

James, N.P., Feary, D.A., Surlyk, F., Toni Simo, J.A., Betzler, C., Holbourn, A.E., Li, Q., Matsuda, H., Machiyama, H., Brooks, G.R., Andres, M.S., Hine, A.C., and Malone, M.J.: Quaternary bryozoan reef mounds in cool-water, upper slope environments: Great Australian Bight, Geology, 28, 2000.

Jiang, C., Chen, Z., Lavoie, D., Percival, J.B., and Kabanov, P.: Mineral carbon MinC (\%) from Rock-Eval analysis as a reliable and cost-effective measurement of carbonate contents in shale source and reservoir rocks, Mar Petrol Geol, 83, 184-194, 2017.

Johnson, T.C.: Sedimentary processes and signals of past climate change in the large lakes of East African Rift Valley, in: Limnology, Climatology and Paleoclimatology of the East African Lakes, edited by: Johnson, T.C. and Odada, E.O., The Gordon and Breach, Amsterdam, 367-412, 1996.

Jorissen, F.J.: The distribution of benthic foraminifera in the Adriatic Sea, Mar Micropaleontol, 12, 21-48, 1987.

Kano, A., Ferdelman, T.G., Williams, T., Henriet, J.-P., Ishikawa, T., Kawagoe, N., Takashima, C., Kakizaki, Y., Abe, K., Sakai, S., Browning, E.L., and Li, X.: Age constraints on the origin and growth history of a deep-water coral mound in the northeast Atlantic drilled during Integrated Ocean Drilling Program Expedition 307, Geology, 35, 2007.

Katz, E.J.: The Levantine Intermediate Water between the Strait of Sicily and the Strait of Gibraltar, Deep-Sea Res, 19, 507-520, 1972.

Kenyon, N.H., Akhmetzhanov, A.M., Wheeler, A.J., van Weering, T.C.E., de Haas, H., and Ivanov, M.K.: Giant carbonate mud mounds in the southern Rockall Trough, Mar Geol, 195, 5-30, 2003. 
Knippertz, P., Christoph, M., and Speth, P.: Long-term precipitation variability in Morocco and the link to the largescale circulation in recent and future climates, Meteorol Atmos Phys, 83, 67-88, 2003.

Koho, K.A., García, R., de Stigter, H.C., Epping, E., Koning, E., Kouwenhoven, T.J., and van der Zwaan, G.J.: Sedimentary labile organic carbon and pore water redox control on species distribution of benthic foraminifera: A case study from Lisbon-Setúbal Canyon (southern Portugal), Prog Oceanogr, 79, 55-82, 2008.

Kudras, H.R. and Thiede, J.: Stratigraphisehe Untersuehungen an Sedimentkernen des ibero-marokkanisehen Kontinentalrandes, Geol. Rundsch, 60, 294-391, 1970.

Lavaysse, C., Flamant, C., Janicot, S., Parker, D.J., Lafore, J.-P., Sultan, B., and Pelon, J.: Seasonal evolution of the West African heat low: a climatological perspective, Clim Dyn, 33, 313-330, 2009.

La Violette, P.E.: The Advection of Submesoscale Thermal Features in the Alboran Sea Gyres, J Phys Oceanogr, 14, 550-565, 1983.

Lafuente, J.G., Camno, N., Vargas, M., Rubín, J.P., and Hernández-Guerra, A.: Evolution of the Alboran Sea hydrographic structures during July 1993, Deep-Sea Res Pt I, 45, 39-65, 1998.

Lanoix, R.: Projet Alboran: étude hydrologique et dynamique de la mer d'Alboran, Technical Report 66, NATO, Brussels, Belgium, 1974.

Lebreiro, S.M., Moreno, J.C., McCave, I.N., and Weaver, P.P.E.: Evidence for Heinrich layers off Portugal (Tore Seamount: 39”N, 12”W), Mar Geol, 131, 47-56, 1996.

Linke, P. and Lutze, G.F.: Microhabitat preferences of benthic foraminifera-a static concept or a dynamic adaptation to optimize food acquisition?, Mar Micropaleontol, 20, 215-234, 1993.

Lionello, P., Trigo, I.F., Gil, V., Liberato, M.L.R., Nissen, K.M., Pinto, J.G., Raible, C.C., Reale, M., Tanzarella, A., Trigo, R.M., Ulbrich, S., and Ulbrich U.: Objective climatology of cyclones in the Mediterranean region: a consensus view among methods with different system identification and tracking criteria, Tellus A, 68, 1, 29391, 2016.

Lisiecki, L.E. and Raymo, M.E.: A Pliocene-Pleistocene stack of 57 globally distributed benthic $\delta^{18} \mathrm{O}$ records, Paleoceanography, 20, PA1003, 2005.

Llave, E., Schönfeld, J., Hernández-Molina, F.J., Mulder, T., Somoza, L., Díaz del Río, V., and Sánchez-Almazo, I.: High-resolution stratigraphy of the Mediterranean outflow contourite system in the Gulf of Cádiz during the late Pleistocene: The impact of Heinrich events, Mar Geol, 227, 241-262, 2006.

Lo Iacono, C., Gràcia, E., Ranero, C.R., Emelianov, M., Huvenne, V.A.I., Bartolomé, R., Booth-Rea, G., Prades, J., Ambroso, S., Dominguez, C., Grinyó, J., Rubio, E., and Torrent, J.: The West Melilla cold water coral mounds, Eastern Alboran Sea: Morphological characterization and environmental context, Deep-Sea Res Pt II, 99, 316326, 2014.

López Casado, C., Sanz de Galdeano, C., Molina Palacios, S., and Henares Romero, J.: The structure of the Alboran Sea: an interpretation from seismological and geological data, Tectonophysics, 338, 79-95, 2001.

López Correa, M., Montagna, P., Joseph, N., Rüggeberg, A., Fietzke, J., Flögel, S., Dorschel, B., Goldstein, S.L., Wheeler, A., and Freiwald, A.: Preboreal onset of cold-water coral growth beyond the Arctic Circle revealed by coupled radiocarbon and U-series dating and neodymium isotopes, Quaternary Sci Rev, 34, 24-43, 2012. 
Lutze, G.F. and Coulbourn, W.T.: Recent benthic foraminifera from the continental margin of Northwest Africa: community structure and distribution, Mar Micropaleontol, 8, 361-401, 1984.

Mackensen, A., Schmiedl, G., Harloff, J., and Giese, M.: Deep-sea foraminifera in the South Atlantic Ocean: Ecology and assemblage generation, Micropaleontology, 41, 342-358, 1995.

Magri, D. and Parra, I.: Late Quaternary western Mediterranean pollen records and African winds, Earth Planet Sc Lett, 200, 401-408, 2002.

Margreth, S., Rüggeberg, A., and Spezzaferri, S.: Benthic foraminifera as bioindicator for cold-water coral reef ecosystems along the Irish margin, Deep-Sea Res Pt I, 56, 2216-2234, 2009.

Martrat, B., Grimalt, J.O., Lopez-Martinez, C., Cacho, I., Sierro, F.J., Flores, J.A., Zahn, R., Canals, M., Curtis, J.H., and Hodell, D.A.: Abrupt temperature changes in the Western Mediterranean over the past 250,000 years, Science, 306, 1762-1765, 2004.

Masqué, P., Fabres, J., Canals, M., Sanchez-Cabeza, J.A., Sanchez-Vidal, A., Cacho, I., Calafat, A.M., and Bruach, J.M: Accumulation rates of major constituents of hemipelagic sediments in the deep Alboran Sea: a centennial perspective of sedimentary dynamics, Mar Geol, 193, 207-33, 2003.

Mastrototaro F., D’Onghia G., Corriero G., Matarrese A., Maiorano P., Panetta P., Gherardi M., Longo C., Rosso A., Sciuto F., Sanfilippo R., Gravili C., Boero F, Taviani M., and Tursi A.: Biodiversity of the white coral bank off Cape Santa Maria di Leuca (Mediterranean Sea): An update, Deep-Sea Res Pt II, 57, 5-6, 412-430, 2010. doi 10.1016/j.dsr2.2009.08.021.

Matos, L., Mienis, F., Wienberg, C., Frank, N., Kwiatkowski, C., Groeneveld, J., Thil, F., Abrantes, F., Cunha, M.R., and Hebbeln, D.: Interglacial occurrence of cold-water corals off the Cape Lookout (NW Atlantic): First evidence of the Gulf Stream influence, Deep-Sea Res Pt I, 105, 158-170, 2015.

Matos, L., Wienberg, C., Titschack, J., Schmiedl, G., Frank, N., Abrantes, F., Cunha, M.R., and Hebbeln, D.: Coral mound development at the Campeche cold-water coral province, southern Gulf of Mexico: Implications of Antarctic Intermediate Water increased influence during interglacials, Mar Geol, 392, 53-65, 2017.

McCave, I.N. and Hall, I.R.: Size sorting in marine muds: Processes, pitfalls, and prospects for paleoflow-speed proxies, Geochem Geophy Geosy, 7, 2006.

McCave, I.N., Manighetti, B., and Robinson, S.G.: Sortable silt and fine sediment size/composition slicing: Parameters for palaeocurrent speed and palaeoceanography, Paleoceanography, 10, 593-610, 1995.

McCave, I.N., Thornalley, D.J.R., and Hall, I.R.: Relation of sortable silt grain-size to deep-sea current speeds: Calibration of the 'Mud Current Meter', Deep-Sea Res Pt I, 127, 1-12, 2017.

Mienis, F., de Stigter, H.C., White, M., Duineveld, G., de Haas, H., and van Weering, T.C.E.: Hydrodynamic controls on cold-water coral growth and carbonate-mound development at the SW and SE Rockall Trough Margin, NE Atlantic Ocean, Deep-Sea Res Pt I, 54, 1655-1674, 2007.

Mienis, F., Duineveld, G.C.A., Davies, A.J., Ross, S.W., Seim, H., Bane, J., and can Weering, T.C.E.: The influence of near-bed hydrodynamic conditions on cold-water corals in the Viosca Knoll area, Gulf of Mexico, Deep-Sea Res Pt I, 60, 32-45, 2012. 
Milker, Y., Schmiedl, G., Betzler, C., Römer, M., Jaramillo-Vogel, D., and Siccha, M.: Distribution of recent benthic foraminifera in shelf carbonate environments of the Western Mediterranean Sea, Mar Micropaleontol, 73, 207 $225,2009$.

Millot, C.: Circulation in the western Mediterranean Sea, J Marine Syt, 20, 423-442, 1999.

Millot, C.: Another description of the Mediterranean Sea outflow, Prog Oceanogr, 82, 101-124, 2009.

Millot, C.: Levantine Intermediate Water characteristics: an astounding general misunderstanding!, Sci Mar, 77, 217232, 2013.

Millot, C., Candela, J., Fuda, J.-L., and Tber, Y.: Large warming and salinification of the Mediterranean outflow due to changes in its composition, Deep-Sea Res Pt I, 53, 656-666, 2006.

Mohn, C., Rengstorf, A., White, M., Duineveld, G., Mienis, F., Soetaert, K., and Grehan, A.: Linking benthic hydrodynamics and cold-water coral occurrences: A high-resolution model study at three cold-water coral provinces in the NE Atlantic, Prog Oceanogr, 122, 92-104, 2014.

Mojtahid, M., Jorissen, F., Lansard, B., Fontanier, C., Bombled, B., and Rabouille, C.: Spatial distribution of live benthic foraminifera in the Rhône prodelta: Faunal response to a continental-marine organic matter gradient, Mar Micropaleontol, 70, 177-200, 2009.

Murray, J.W.: Ecology and Applications of Benthic Foraminifera, Cambridge University Press, 2006.

Negri, M.P. and Corselli, C.: Bathyal Mollusca from the cold-water coral biotope of Santa Maria di Leuca (Apulian margin, southern Italy), Zootaxa, 4186, 2016.

Olivet, J.L., Auzende, J.M., and Bonnin, J.: Structure et évolution tectonique du bassin d'Alboran, B Soc Geol Fr, 7 , 491-495, 1973.

Osborne, A.H., Vance, D., Rohling, E.J., Barton, N., Rogerson, M., and Fello, N.: A humid corridor across the Sahara for the migration of early modern humans out of Africa 120,000 years ago, PNAS 105, 16444-16447, 2008.

Pasquier, V., Toucanne, S., Sansjofre, P., Dixit, Y., Revillon, S., Mokeddem, Z., and Rabineau, M.: Organic matter isotopes reveal enhanced rainfall activity in Northwestern Mediterranean borderland during warm substages of the last 200 ky, Quaternary Sci Rev, 205, 182-192, 2018

Pérez-Folgado, M., Sierro, F.J., Flores, J.A., Grimalt, J.O., and Zahn, R.: Paleoclimatic variations in foraminifer assemblages from the Alboran Sea (Western Mediterranean) during the last $150 \mathrm{ka}$ in ODP Site 977, Mar Geol, 212, 113-131, 2004.

Phleger, F.B. and Soutar, A.: Production of Benthic Foraminifera in Three East Pacific Oxygen Minima, Micropaleontology, 19, 110-115, 1973.

1055 Pomar, L., Morsilli, M., Hallock, P., and Bádenas, B.: Internal waves, and under-explored source of turbulence events in the sedimentary record, Earth Sci Rev, 111, 56-81, 2012.

R Core Team.: R: A language and environment for statistical computing, R Foundation for Statistical Computing, Vienna, Austria, URL https://www.R-project.org/., 2018

Rabineau, M., Berné, S., Olivet, J-L., Aslanian, D., Guillocheau, F., and Joseph, P.: Paleo sea levels reconsidered from direct observation of paleoshoreline position during Glacial Maxima (for the last 500,000 yr), Earth Planet Sc Lett, 252, 119-137, 2006. 
Rachid, J., Hssaida, T., Hamoumi, N., Terhzaz, L., Spezzaferri, S., Frank, N., and Daghor, L.: Palynological study of carbonated mounds during the Holocene along the Atlantic and Mediterranean Moroccan margins, Rev Palaeobot and Palyno, 278, 104213, 2020

Raddatz, J., Rüggeberg, A., Flögel, S., Hathorne, E.D., Liebetrau, V., Eisenhauer, A., and Dullo, W-C.: The influence of seawater $\mathrm{pH}$ on $\mathrm{U} / \mathrm{Ca}$ ratios in the scleractinian cold-water coral Lophelia pertusa, Biogeosciences, 7, 1863-1871, 2014.

Ramsey, C.: OxCal 4.2.4, Electronic document, URL https://c14.arch.ox.ac.uk/oxcal.html., 2017.

Reimer, P.J., Bard, E., Bayliss, A., Beck, J.W., Blackwell, P.G., Ramsey, C.B., Buck, C.E., Cheng, H., Edwards, R.L., Friedrich, M., Grootes, P.M., Guilderson, T.P., Haflidason, H., Hajdas, I., Hatté, C., Heaton, T.J., Hoffmann, D.L., Hogg, A.G., Hughen, K.A., Kaiser, K.F., Kromer, B., Manning, S.W., Niu, M., Reimer, R.W., Richards, D.A., Scott, E.M., Southon, J.R., Staff, R.A., Turney, C.S.M., and van der Plicht, J.: IntCal13 and Marine13 Radiocarbon Age Calibration Curves 0-50,000 Years cal BP, Radiocarbon, 55, 1869-1887, 2013.

Roberts, J.M., Wheeler, A.J., and Freiwald, A.: Reefs of the Deep: The Biology and Geology of Cold-Water Coral Ecosystems, Science, 312, 543-547, 2006.

Roberts, J.M., Wheeler, A.J., Freiwald, A., and Cairns, S.: Cold-Water Corals, Cambridge University Press, 351 pp., 2009.

Rogerson, M., Dublyansky, Y., Hoffmann, D.L., Luetscher, M., Spötl, C., and Töchterle, P.: Enhanced Mediterranean water cycle explains increased humidity during MIS 3 in North Africa, Clim Past Discussions, 1$31,2018$.

Rohling, E.J., Cane, T.R., Cooke, S., Sprovieri, M., Bouloubassi, I., Emeis, K.C., Schiebel, R., Kroon, D., Jorissen, F.J., Lorre, A., and Kemp, A.E.S.: African monsoon variability during the previous interglacial maximum, Earth Planet Sc Lett, 202, 61-75, 2002.

Rüggeberg, A., Dullo, C., Dorschel, B., and Hebbeln, D.: Environmental changes and growth history of a cold-water carbonate mound (Propeller Mound, Porcupine Seabight), Int J Earth Sci, 96, 57-72, 2007.

Sachs, J.P. and Lehman, S.J.: Subtropical North Atlantic Temperatures 60,000 to 30,000 Years Ago, Science, 286, 756-759, 1999.

Schiebel, R. and Hemleben, C.: Planktic Foraminifers in the Modern Ocean, Springer-Verlag, Berlin, Heidelberg, 358 pp., 2017.

Schmiedl, G., De Bovée, F., Buscail, R., Charriere, B., Hemleben, C., Medernach, L., and Picon, P.: Trophic control of benthic foraminiferal abundance and microhabitat in the bathyal Gulf of Lions, western Mediterranean Sea, Mar Micropaleontol, 40, 167-188, 2000.

Schmiedl, G., Kuhnt, T., Ehrmann, W., Emeis, K.-C., Hamann, Y., Kotthoff, U., Dulski, P., and Pross, J.: Climatic forcing of eastern Mediterranean deep-water formation and benthic ecosystems during the past 22000 years, Quaternary Sci Rev, 29, 3006-3020, 2010.

Scholz, J. and Hillmer, G.: Reef-Bryozoans and Bryozoan-Microreefs: Control Factor Evidence from the Philippines and other Regions, Facies, 32, 109-144, 1995.

Schönfeld, J.: Recent benthic foraminiferal assemblages in deep high-energy environments from the Gulf of Cádiz (Spain), Mar Micropaleontol, 44, 141-162, 2002. 

foraminiferal assemblages and stable isotopes at the Portuguese margin, Palaeogeogr Palaeocl, 159, 85-111, 2000.

Shanahan, T.M., McKay, N.P., Hughen, K.A., Overpeck, J.T., Otto-Bliesner, B., Heil, C.W., Scholz, C.A., and Peck, J.: The time-transgressive termination of the African Humid Period, Nat Geosci, 8, 140-144, 2015. reservoir ages in the Mediterranean Sea and Black Sea, Radiocarbon, 42, 2, 271-280, 2000.

Sierro, F.J., Hodell, D.A., Curtis, J.H., Flores, J.A., Reguera, I., Colmenero-Hidalgo, E., Bárcena, M.A., Grimalt, J.O., Cacho, I., Frigola, J., and Canals, M.: Impact of iceberg melting on Mediterranean thermohaline circulation during Heinrich events, Paleoceanography, 20, 2005.

Snousi, M.: Review of Certain Basic Elements for the Assessment of Environmental Flows in the Lower Moulouya, IUCN International Union for Conservation of Nature, Gland, Switzerland, 2004. Available online: http://cmsdata.iucn.org/downloads/morocco.pdf (accessed on 20 August 2012).

Sparnocchia, S., Picco, P., Manzella, G., Ribotti, A., Copello, S., and Brasey, P.: Intermediate water formation in the Ligurian Sea, Oceanol Acta, 18, 151-162, 1995.

Spezzaferri, S., Rüggeberg, A., Stalder, C., and Margreth, S.: Benthic foraminiferal assemblages from cold-water coral ecosystems, in: Atlas of Benthic Foraminifera From Cold-Water Coral Reefs, edited by: Spezzaferri, S., Rüggeberg, A., and Stalder, C., Special Publication/Cushman Foundation For Foraminiferal Research, 20-48, 2014.

Spötl C. and Vennemann T.W.: Continuous-flow IRMS analysis of carbonate minerals, Rapid Commun Mass Sp, 17, 1004-1006, 2003.

Stalder, C., Vertino, A., Rosso, A., Ruggeberg, A., Pirkenseer, C., Spangenberg, J.E., Spezzaferri, S., Camozzi, O., Rappo, S., and Hajdas, I.: Microfossils, a Key to Unravel Cold-Water Carbonate Mound Evolution through Time: Evidence from the Eastern Alboran Sea, PLoS One, 10, e0140223, 2015.

Stalder, C., El Kateb, A., Vertino, A., Rüggeberg, A., Camozzi, O., Pirkenseer, C.M., Spangenberg, J.E., Hajdas, I., Van Rooij, D., and Spezzaferri, S.: Large-scale paleoceanographic variations in the western Mediterranean Sea during the last 34,000 years: From enhanced cold-water coral growth to declining mounds, Mar Micropaleontol, 143, 46-62, 2018.

Stanley, J.D., Kelling, G., Vera, J.A., and Sheng, H.: Sands in the Alboran Sea: A Model of Input in a Deep Marine Basin, SM C Earth Sci, 1-51, 1975.

Suhr, S.B., Pond, D.W., Gooday, A.J., and Smith, C.R.: Selective feeding by benthic foraminifera on phytodetritus on the western Antarctic Peninsula shelf: Evidence from fatty acid biomarker analysis, Mar Ecol Prog Ser, 262, 153-162, 2003.

Sun, X., Corliss, B.H., Brown, C.W., and Showers, W.J.: The effect of primary productivity and seasonality on the distribution of deep-sea benthic foraminifera in the North Atlantic, Deep-Sea Res Pt I, 53, 28-47, 2006. 
Talbot, M.R. and Livingstone, D.A.: Hydrogen index and carbon isotopes of lacustrine organic matter as lake level indicators, Palaeogeogr Palaeocl, 70, 121-137, 1989.

Tekken, V. and Kropp, J.P.: Climate-driven or human-induced; indicating severe water scarcity in the Moulouya River basin (Morocco), Water, 4, 959-982, 2012.

Terhzaz, L., Hamoumi, N., Spezzaferri, S., El Mostapha L., and Henriet, J.P.: Carbonate mounds of the Moroccan Mediterranean margin: Facies and environmental controls, C R Geosci, 350, 212-221. 2018.

Titschak, J., Thierens, M., Dorschel, B., Schulbert, C., Freiwald, A., Kano, A., Takashima, C., Kawagoe, N., Li, X., and IODP Expedition 307 scientific party.: Carbonate budget of a cold-water coral mound (Challenger Mound, IODP Exp. 307), Mar Geol, 259, 36-46, 2009.

Toucanne, S., Mulder, T., Schönfeld, J., Hanquiez, V., Gonthier, E., Duprat, J., Cremer, M., and Zaragosi, S.: Contourites of the Gulf of Cádiz: A high-resolution record of the paleocirculation of the Mediterranean outflow water during the last 50,000 years, Palaeogeogr Palaeocl, 246, 354-366, 2007.

Toucanne, S., Jouet, G., Ducassou, E., Bassetti, M.-A., Dennielou, B., Angue Minto'o, C.M., Lahmi, M., Touyet, N., Charlier, K., Lericolais, G., and Mulder, T.: A 130,000-year record of Levantine Intermediate Water flow variability in the Corsica Trough, western Mediterranean Sea, Quaternary Sci Rev, 33, 55-73, 2012.

Tuenter, E., Weber, S.L., Hilgen, F.J., and Lourens, L.J.: The response of the African summer monsoon to remote and local forcing due to precession and obliquity, Global Planet. Change, 36, 219-235, 2003.

Van Krevelen, D.W.: Coal: typology-physics-chemistry-constitution, 3rd edition, Elsevier Science Publishers, 1993.

Van Rooij, D., Hebbeln, D., Comas, M., Vandorpe, T., Delivet, S., and the shipboard scientific party,: EUROFLEETS Cruise Summary Report, The Mediterranean-Atlantic Gateway Code: The Late Pleistocene Carbonate Mound Record, 2013.

Viúdez, Á. and Tintoré, J.: Time and space variability in the Eastern Alboran Sea from March to May 1990, J Geophys Res, 100, 1995.

Wang, H., Lo Iacono, C., Wienberg, C., Titschack, J., and Hebbeln, D.: Cold-water coral mounds in the southern Alboran Sea (western Mediterranean Sea): Internal waves as an important driver for mound formation since the last deglaciation, Mar Geol, 412, 1-18, 2019.

Wefing, A.-M., Arps, J., Blaser, P., Wienberg, C., Hebbeln, D., and Frank, N.: High precision U-series dating of 1165 scleractinian cold-water corals using an automated chromatographic U and Th extraction, Chem Geol, 475, 140148, 2017.

Wehrmann, L.M., Knab, N.J., Pirlet, H., Unnithan, V., Wild, C., and Ferdelman, T.G.: Carbon mineralization and carbonate preservation in modern cold-water coral reef sediments on the Norwegian shelf, Biogeosciences, 6 , 663-680, 2009.

White, M.: Benthic dynamics at the carbonate mound regions of the Porcupine Sea Bight continental margin, Int J Earth Sci96, 1-9, 2007.

White, M., Mohn, C., De Stigter, H.C., and Mottram, G.: Deep-water coral development as a function of hydrodynamics and surface productivity around the submarine banks of the Rockall Trough, NE Atlantic, in: 
Cold-water Corals and Ecosystems, edited by: Freiwald, A. and Roberts, J.M., Springer-Verlag, Berlin, Heidelberg, 503-514 pp., 2005.

Wickham, H.: ggplot2: Elegant Graphics for Data Analysis, Springer-Verlag, New York, 2016.

Wienberg, C.: A deglacial cold-water coral boom in the Alboran Sea: From coral mounds and species dominance, in: Mediterranean cold-water corals: past, present and future, edited by: Orejas, C. and Jiménez, C., Springer, 5760, 2019.

Wienberg, C. and Titschak, J.: Framework-forming scleractinian cold-water corals through space and time: a Late Quaternary North Atlantic perspective, in: Marine Animal Forests, edited by: Rossi, S., Springer, Switzerland, 2015.

Wienberg, C., Hebbeln, D., Fink, H.G., Mienis, F., Dorschel, B., Vertino, A., Correa, M.L., and Freiwald, A.: Scleractinian cold-water corals in the Gulf of Cádiz-First clues about their spatial and temporal distribution, Deep-Sea Res Pt I, 56, 1873-1893, 2009.

Wienberg, C., Frank, N., Mertens, K.N., Stuut, J.-B., Marchant, M., Fietzke, J., Mienis, F., and Hebbeln, D.: Glacial cold-water coral growth in the Gulf of Cádiz: Implications of increased palaeo-productivity, Earth Planet Sc Lett, 298, 405-416, 2010.

Wienberg, C., Titschack, J., Freiwald, A., Frank, N., Lundälv, T., Taviani, M., Beuck, L., Schröder-Ritzrau, A., Krengel, T., Hebbeln, D.: The giant Mauritanian cold-water coral mound province: Oxygen control on coral mound formation, Quaternary Sci Rev, 185, 135-152, 2018.

Wilson, J.B.: 'Patch' development of the deep-water coral Lophelia Pertusa (L.) on Rockall Bank, J Mar Biol Assoc UK, 59, 1979.

Winston, J.E.: Feeding in marine bryozoans, in Biology of Bryozoans, edited by: Woollacott, R.M. and Zimmer, R.L., 233-271 pp., Academic, San Diego, Calif., 1977.

Winston, J. E.: Feeding behaviour of modern bryozoans, in Lophophorates: Notes for a Short Course, Stud. Geol., vol. 5, edited by: Broadhead, T.W., 1-21 pp., Univ. of Tenn., Knoxville, 1981. 

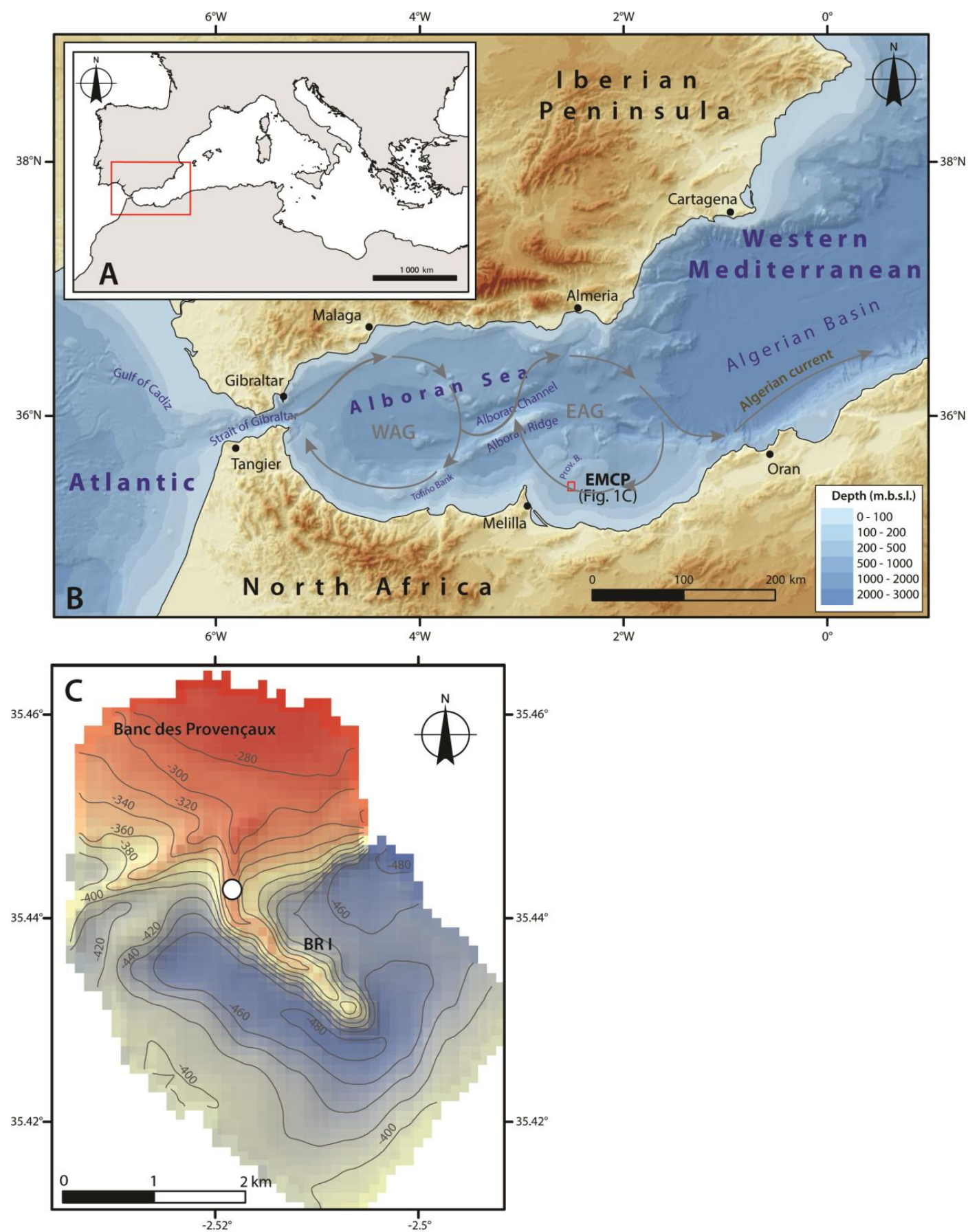
https://doi.org/10.5194/cp-2020-82

Preprint. Discussion started: 26 June 2020

(c) Author(s) 2020. CC BY 4.0 License.

Figure 1. Location of the study area. (A) General map of the Mediterranean Sea and location of the investigated region (B) Bathymetric map of the western Mediterranean Sea based on the GEBCO_2019 gridded bathymetric data. Abbreviations: EMCP: East Melilla Coral Province (red box); WAG: Western Alboran Gyre; EAG: Eastern Alboran Gyre. (C) Bathymetry and location of the Banc des Provençaux and Brittlestar Ridge I (BRI). The white dot indicates the location of the studied core MD13-3462G recovered during cruise "GATEWAY" No. 194 on board the research vessel Marion Dufresne II (Van Rooij et al, 2013), during which the multibeam data used was also acquired using the shipboard $12 \mathrm{kHz}$ multibeam echosounder (Van Rooij et al., 2013).

1215

1220

1225 
https://doi.org/10.5194/cp-2020-82

Preprint. Discussion started: 26 June 2020

(c) Author(s) 2020. CC BY 4.0 License.
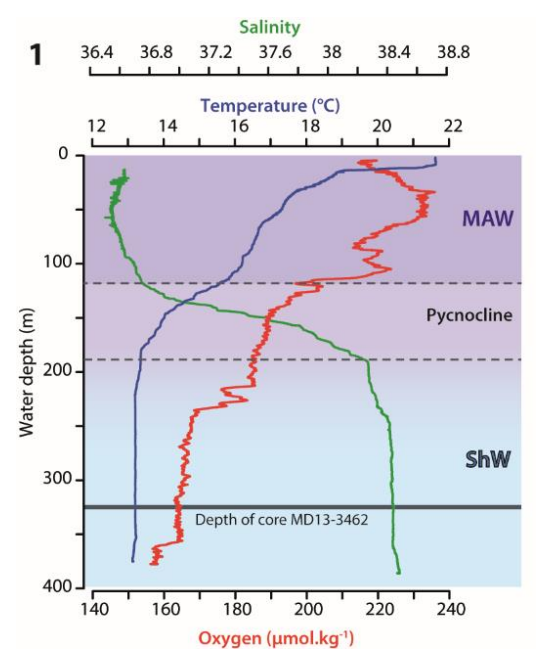

2

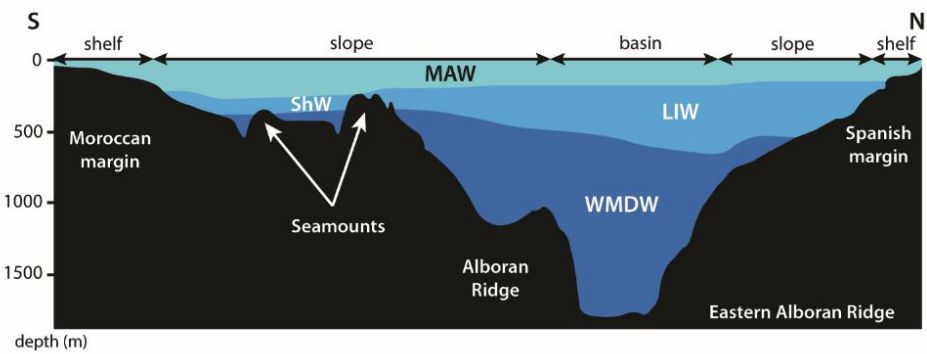

Figure 2. (1) CTD profile taken at the east of Brittlestar Ridge I $\left(35^{\circ} 26,087^{\prime} \mathrm{N} ; 2^{\circ} 30,100^{\prime} \mathrm{W}\right)$ during cruise "GATEWAY" (No. 194) on board the research vessel Marion Dufresne II (Van Rooij et al., 2013). Salinity, temperature $\left({ }^{\circ} \mathrm{C}\right.$ ) and oxygen content $1240\left(\mu \mathrm{mol} . \mathrm{kg}^{-1}\right)$ are indicated. The location of core MD13-3462G in relation to the profile is indicated by the black line. (2) NorthSouth orientated bottom water profile of the East Alboran Sea modified from Ercilla et al. (2016). Abbreviations: MAW: Modified Atlantic Water, ShW: Shelf Water, LIW: Levantine Intermediate Water. 
https://doi.org/10.5194/cp-2020-82

Preprint. Discussion started: 26 June 2020

(c) Author(s) 2020. CC BY 4.0 License.

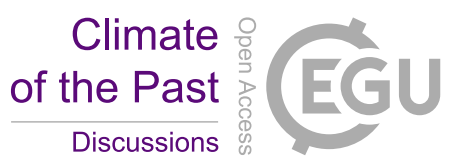

(c) (i)

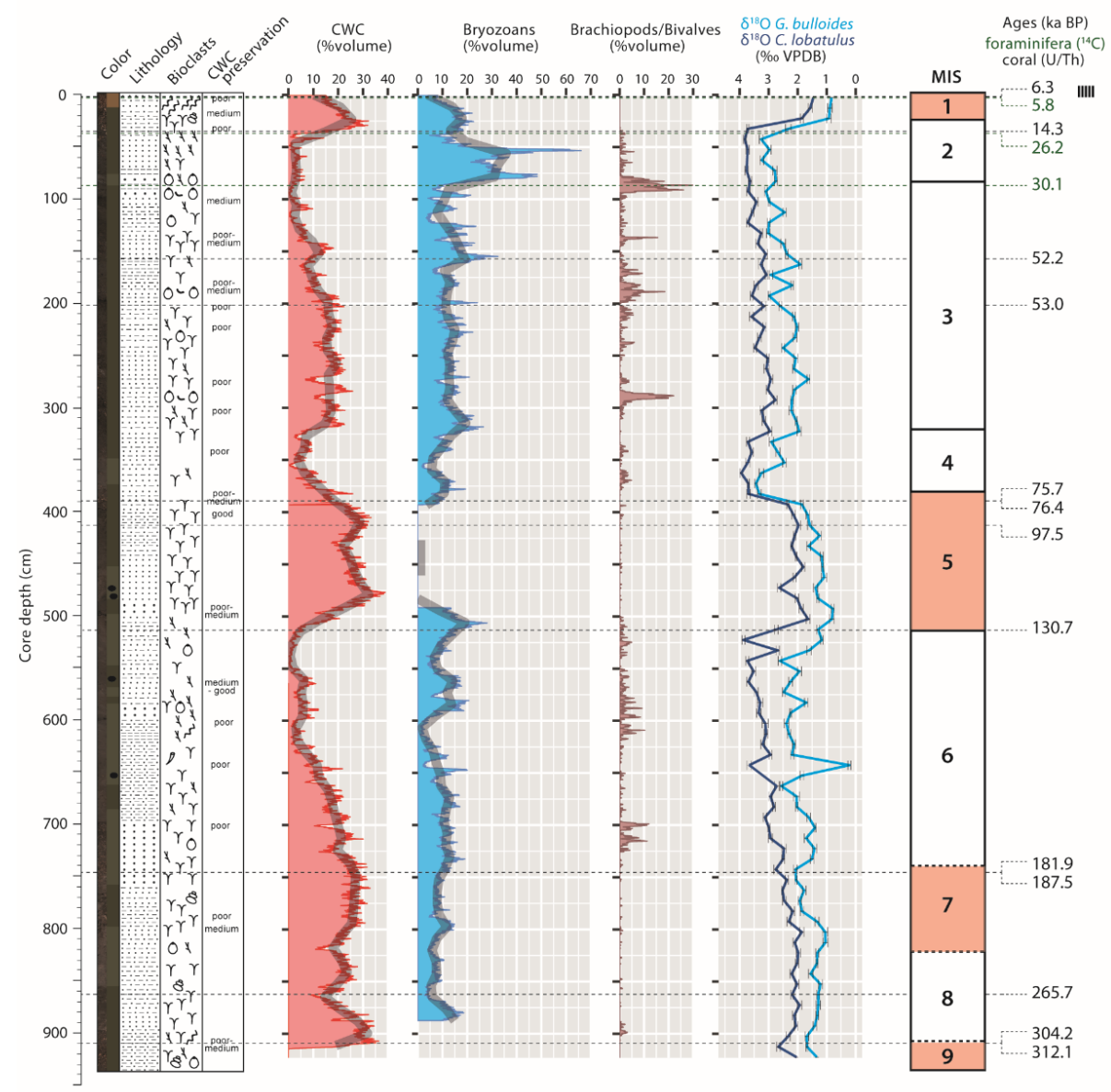

\begin{tabular}{|c|c|c|c|c|c|c|}
\hline Legend & 琵玨 & Clay & 3 & Madrepora oculata & & Interglacial \\
\hline Yellowish/reddish brown & 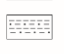 & Clayey silt & $\begin{array}{l}\gamma \\
\text { ○ }\end{array}$ & $\begin{array}{l}\text { Desmophyllum pertusum } \\
\text { Desmophyllum dianthus }\end{array}$ & & Glacial \\
\hline Dark greyish brown & 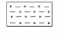 & Silt & $\neq$ & Bryozoan & - & Clear stratigraphic boundary \\
\hline Dark greyish olive & 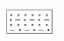 & Silty sand & 0 & Brachiopod & ....... & Ambiguous stratigraphic boundary \\
\hline $\begin{array}{l}\text { Olive grey } \\
\text { Light grey }\end{array}$ & 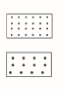 & $\begin{array}{l}\text { Sand } \\
\text { Coarse sand }\end{array}$ & $\begin{array}{l}8 \\
4 \\
-\end{array}$ & $\begin{array}{l}\text { Gastropod } \\
\text { Bivalve } \\
\text { Dark patch }\end{array}$ & |IIIII & Identified hiatus \\
\hline
\end{tabular}

1245 
https://doi.org/10.5194/cp-2020-82

Preprint. Discussion started: 26 June 2020

(C) Author(s) 2020. CC BY 4.0 License.

Figure 3. Core description, stratigraphy and macrofaunal composition of core MD13-3462G. Stratigraphy is based on the planktonic (G. bulloides) and benthic (C. lobatulus) $\delta^{18} \mathrm{O}$ records (\% VPDB), the Uranium-series ages of coral fragments and the epibenthic foraminiferal radiocarbon ages for the first meter of the core (far right). The quantification of the three main macrofaunal components (Cold-water corals: CWC, bryozoans and brachiopods/bivalves) performed through analysis of X-ray Computed Tomography (CT) images is given. Smoothed curves are indicated by the light grey shaded curves. 


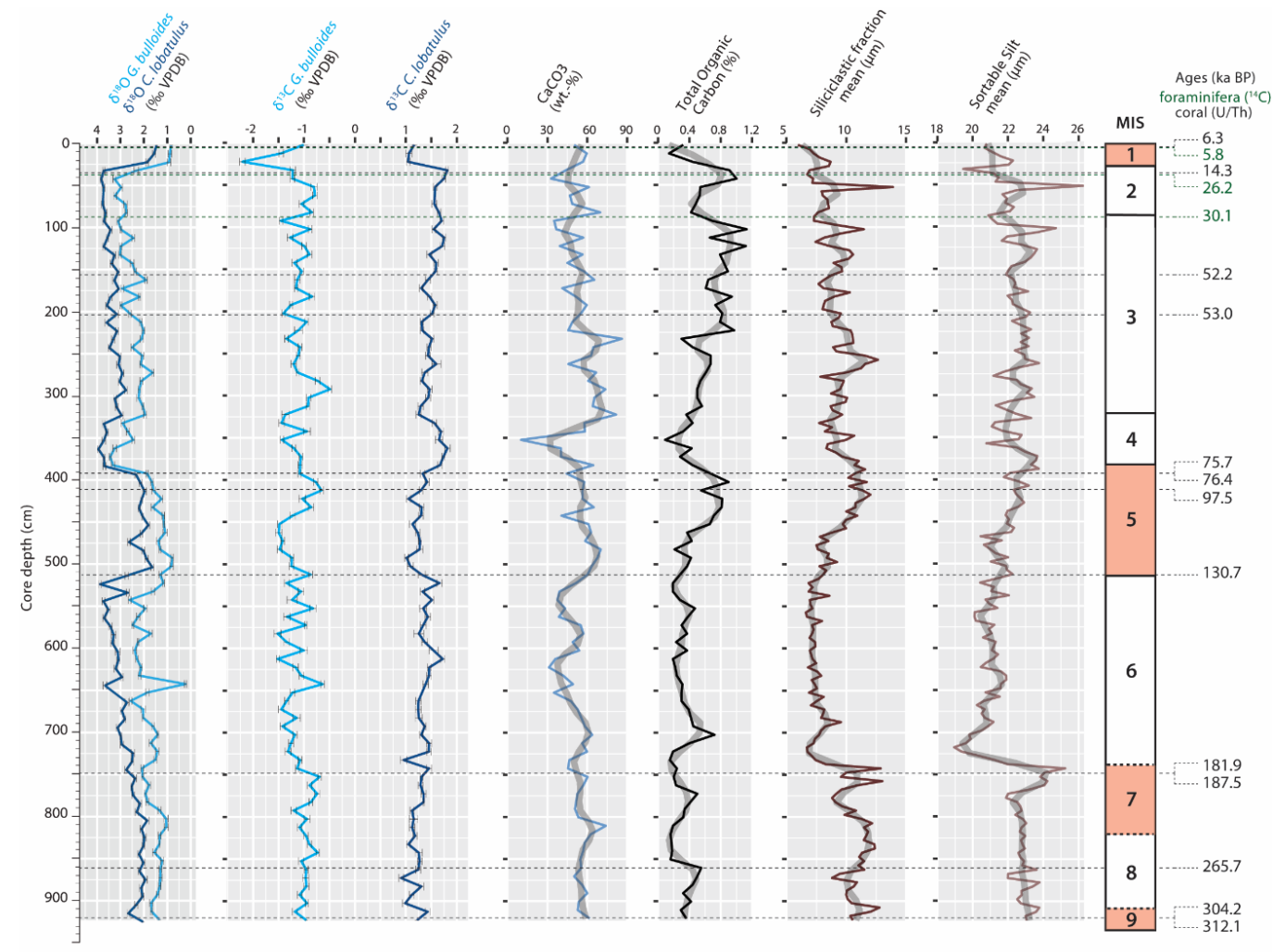

Figure 4. Planktonic (G. bulloides) and benthic (C. lobatulus) $\delta^{13} \mathrm{C}$ records, calcium carbonate $\left(\mathrm{CaCO}_{3}\right)$ content (expressed in weight percentage), Total Organic Carbon content (\%), mean grain size of the siliciclastic fraction $(\mu \mathrm{m})$ and mean grain size of the sortable silt fraction (the 10-63 $\mu \mathrm{m}$ grain size range, expressed in $\mu \mathrm{m}$; McCave et al., 2006). Smoothed curves are indicated by the light grey shaded curves. The stratigraphy defined in Fig. 3 is given to the far right. The planktonic (G. bulloides) and benthic (C. lobatulus) $\delta^{18} \mathrm{O}$ records (\% VPDB) are provided as supporting information. 
https://doi.org/10.5194/cp-2020-82

Preprint. Discussion started: 26 June 2020

(c) Author(s) 2020. CC BY 4.0 License.

(c) (i)

Climate
of the Past
Discussions

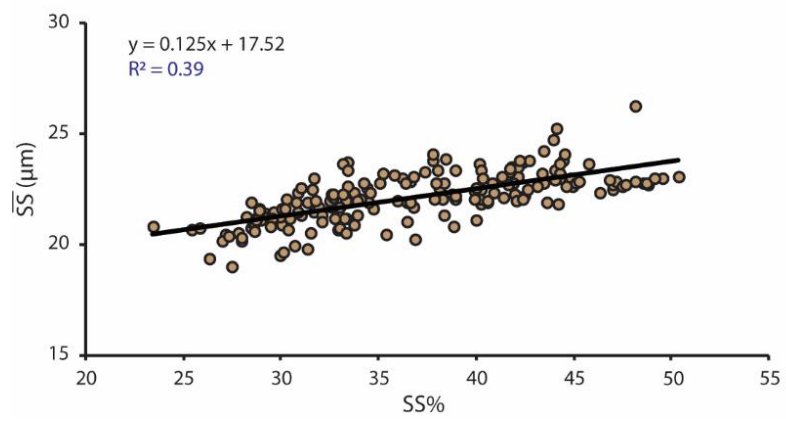

Figure 5. Dispersion plot of the sortable silt mean size (the 10-63 $\mu \mathrm{m}$ grain size range, expressed in $\mu \mathrm{m}$ ) $\overline{\boldsymbol{S S}}$ vs. the percentage of

1270 sortable silt (SS\%). The slope of $0.125 \mu \mathrm{m}$ and intercept at $0 \%$ of $17.52 \mu \mathrm{m}$ indicates a sorting process induced by bottom currents (McCave et al., 2006). 
https://doi.org/10.5194/cp-2020-82

Preprint. Discussion started: 26 June 2020

(c) Author(s) 2020. CC BY 4.0 License.

\section{(c) (i)}
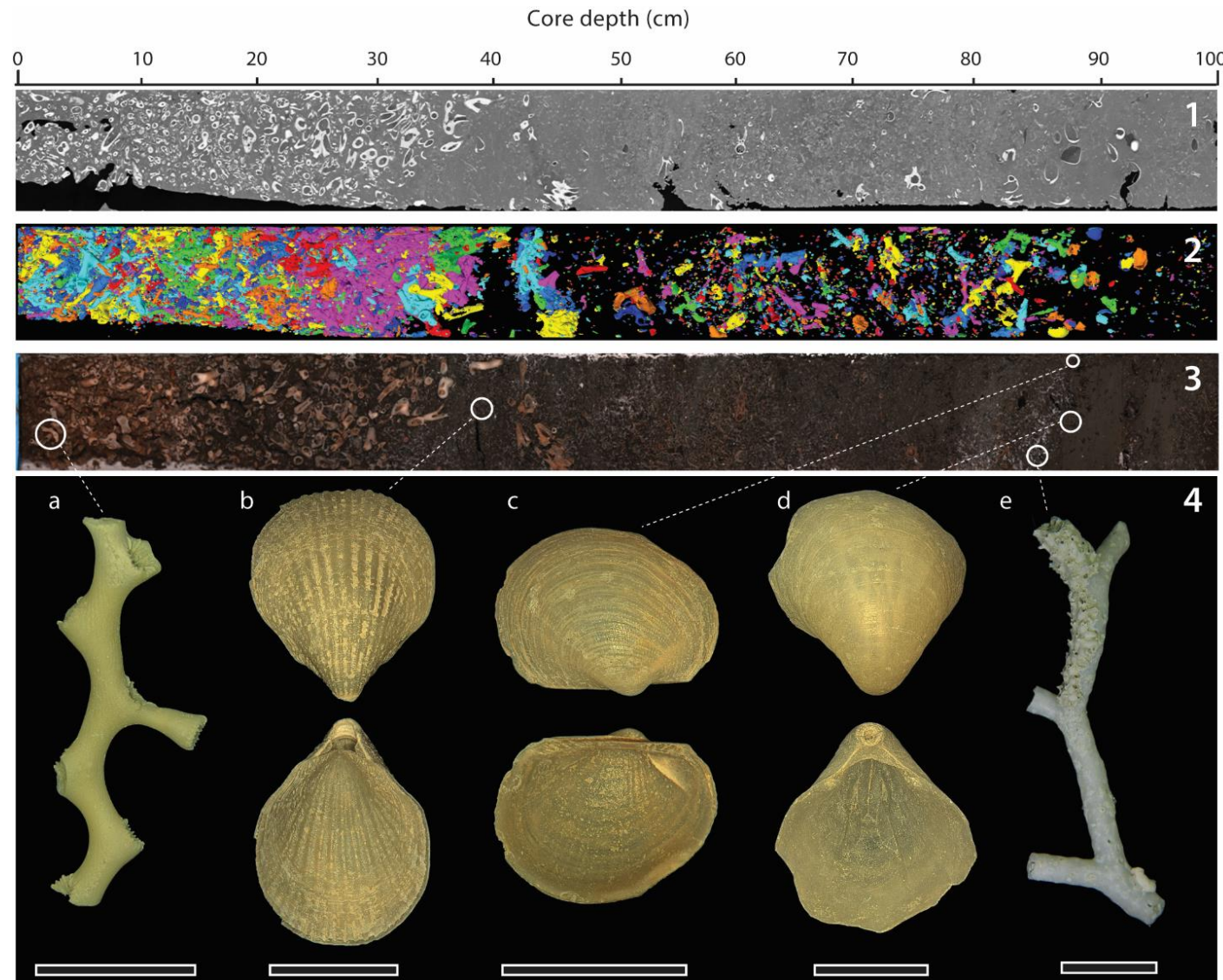

e
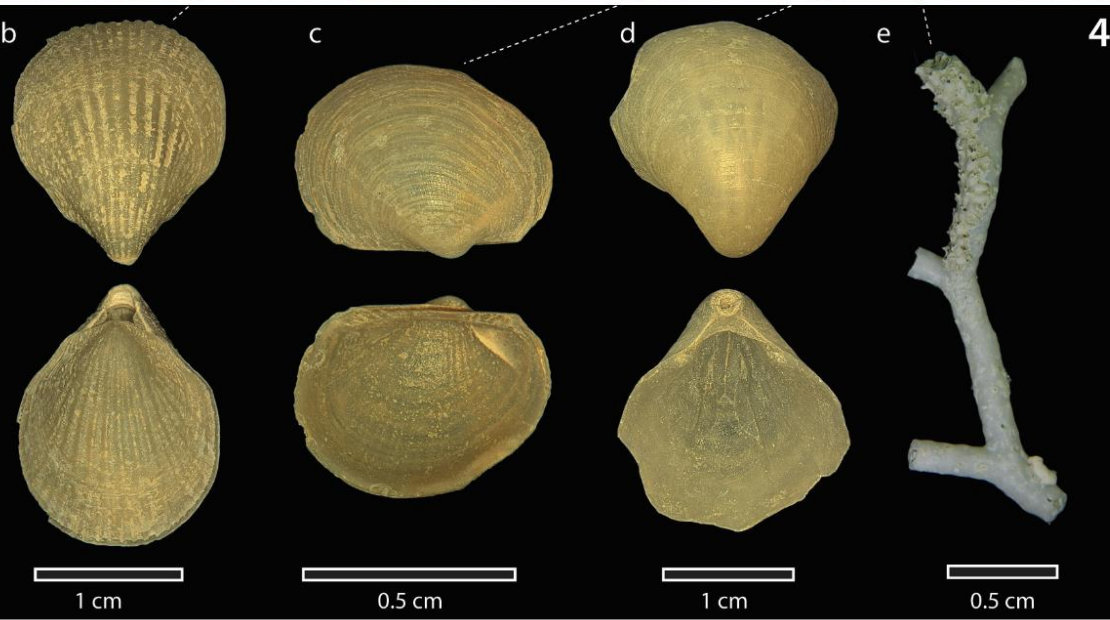

Figure 6. Example of a sediment core section showing the main macrofaunal components (section 1, 0-100 cm). (1) X-ray Computed Tomography imagery. (2) Three-dimensional reconstruction of coral fragments performed on X-ray Computed Tomography (CT) images. (3) Split-core high-resolution image. The white circles indicate the location of main macrofaunal components. (4) Main macrofaunal components: (a) the scleractinian coral Madrepora oculata, (b) the brachiopod Terebratulina retusa, (c) the bivalve Bathyarca pectunculoides, (d) the brachiopod Gryphus vitreus, (e) the bryozoan Buskea dichotoma. 
https://doi.org/10.5194/cp-2020-82

Preprint. Discussion started: 26 June 2020

(c) Author(s) 2020. CC BY 4.0 License.

\section{(c) (1)}
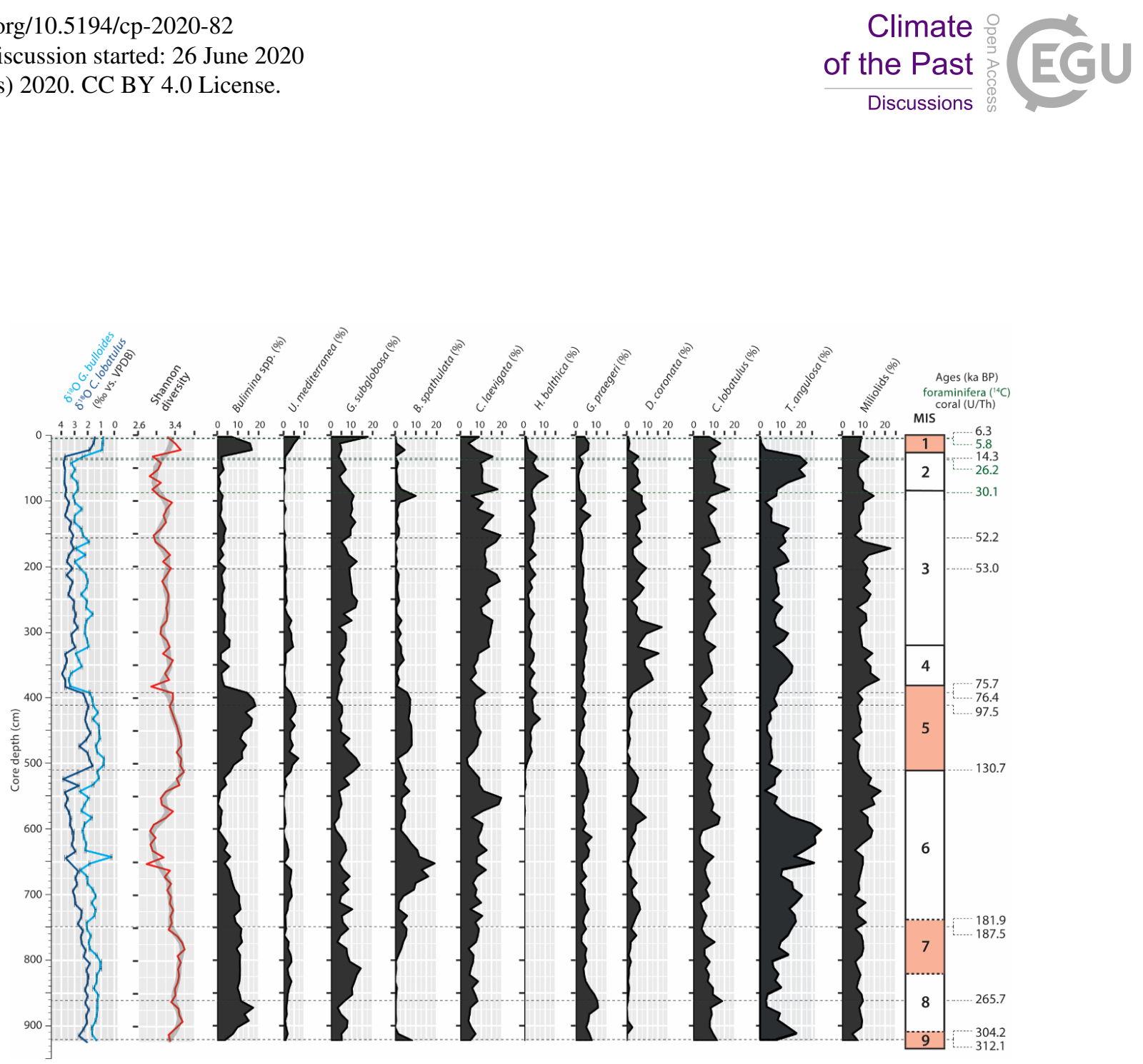

1280 Figure 7. Distribution of main benthic foraminifera (expressed as the percentage of the total number of benthic foraminifera) and benthic foraminiferal Shannon diversity (the overlaid grey curve corresponds to the smoothed curve). The stratigraphy defined in Fig. 3 is given to the far right. The planktonic (G. bulloides) and benthic (C. lobatulus) $\delta^{18} \mathrm{O}$ records (\%, VPDB) are provided as supporting information. 


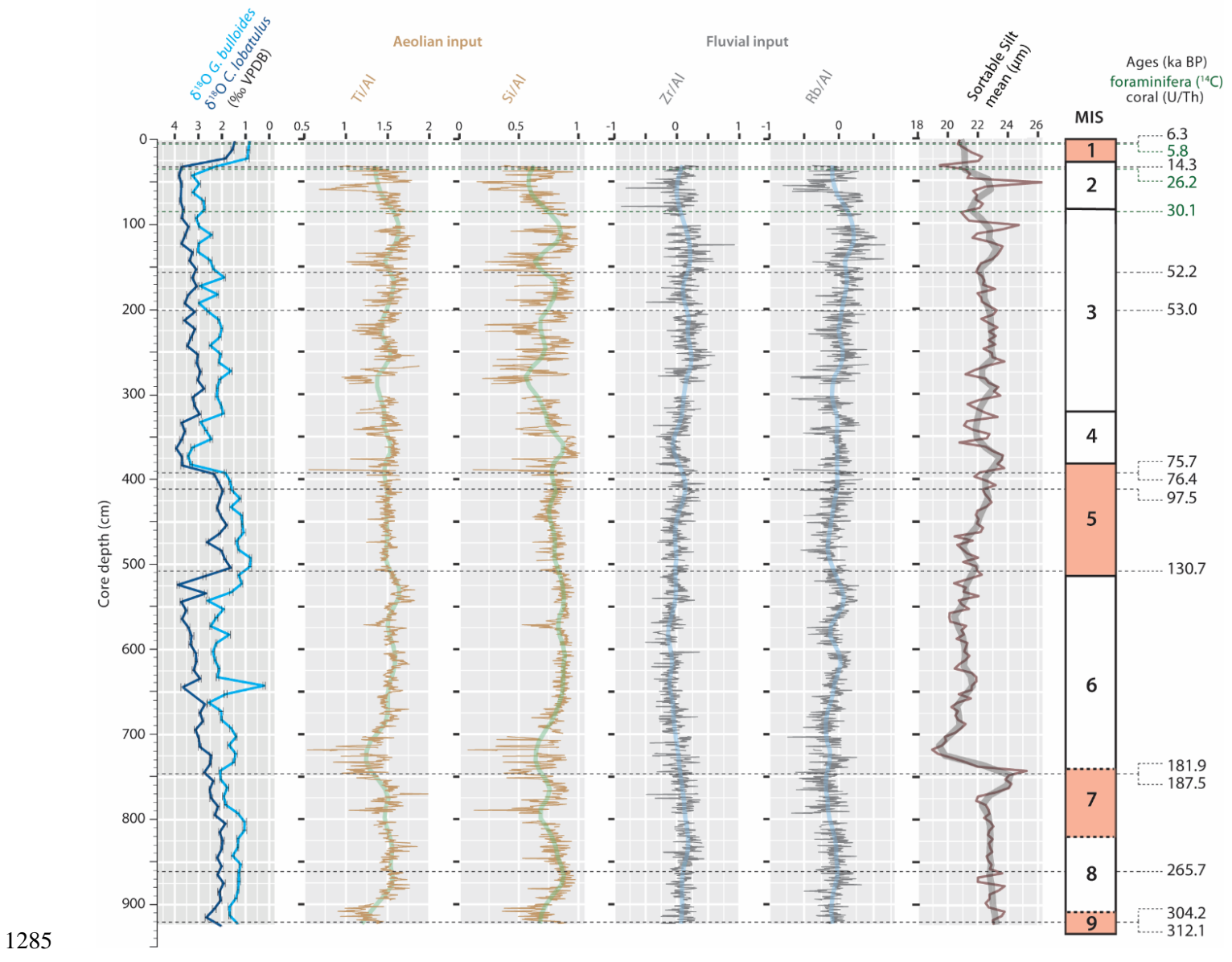

Figure 8. $\log _{10}$ titanium (Ti), silica $(\mathrm{Si})$, zirconium $(\mathrm{Zr})$ and rubidium $(\mathrm{Rb})$ as aluminium (Al)-normalized ratios. These normalized elemental ratios are used as proxies for aeolian ( $\mathrm{Ti} / \mathrm{Al}$ and $\mathrm{Si} / \mathrm{Al})$ and fluvial input $(\mathrm{Zr} / \mathrm{Al}$ and $\mathrm{Rb} / \mathrm{Al})$ at $\mathrm{Brittlestar}$ Ridge I. The stratigraphy defined in Fig. 3 is given to the far right. The planktonic (G. bulloides) and benthic (C. lobatulus) $\delta^{18} \mathrm{O}$ records (\%, VPDB), together with the mean size of the sortable silt fraction (the 10-63 $\mu \mathrm{m}$ grain size range, expressed in $\mu \mathrm{m}$ ), are provided as supporting information. 
https://doi.org/10.5194/cp-2020-82

Preprint. Discussion started: 26 June 2020

(c) Author(s) 2020. CC BY 4.0 License.
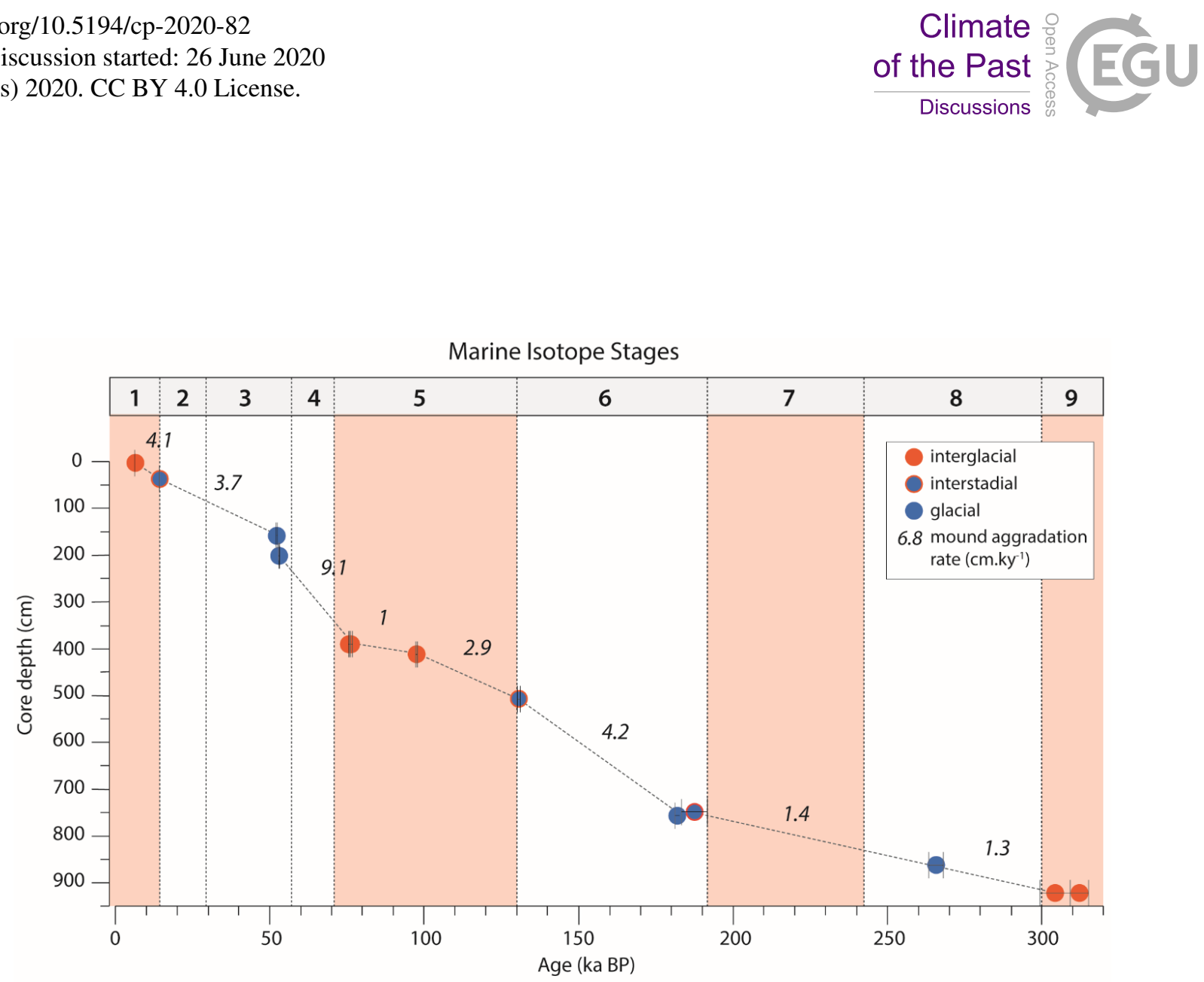

Figure 9. U-series coral ages (ka BP) vs. core depth (cm). Marine Isotope Stages (as defined by Lisiecki and Raymo, 2005) are overlaid. All error bars are $2 \sigma$ of the mean analytical uncertainty. The dashed lines between age-points (see legend) represent average mound aggradation rates (in $\mathrm{cm} \cdot \mathrm{ky}^{-1}$ ). Pink and white columns represent respectively interglacial and glacial periods. 
https://doi.org/10.5194/cp-2020-82

Preprint. Discussion started: 26 June 2020

(c) Author(s) 2020. CC BY 4.0 License.

(c) (1)
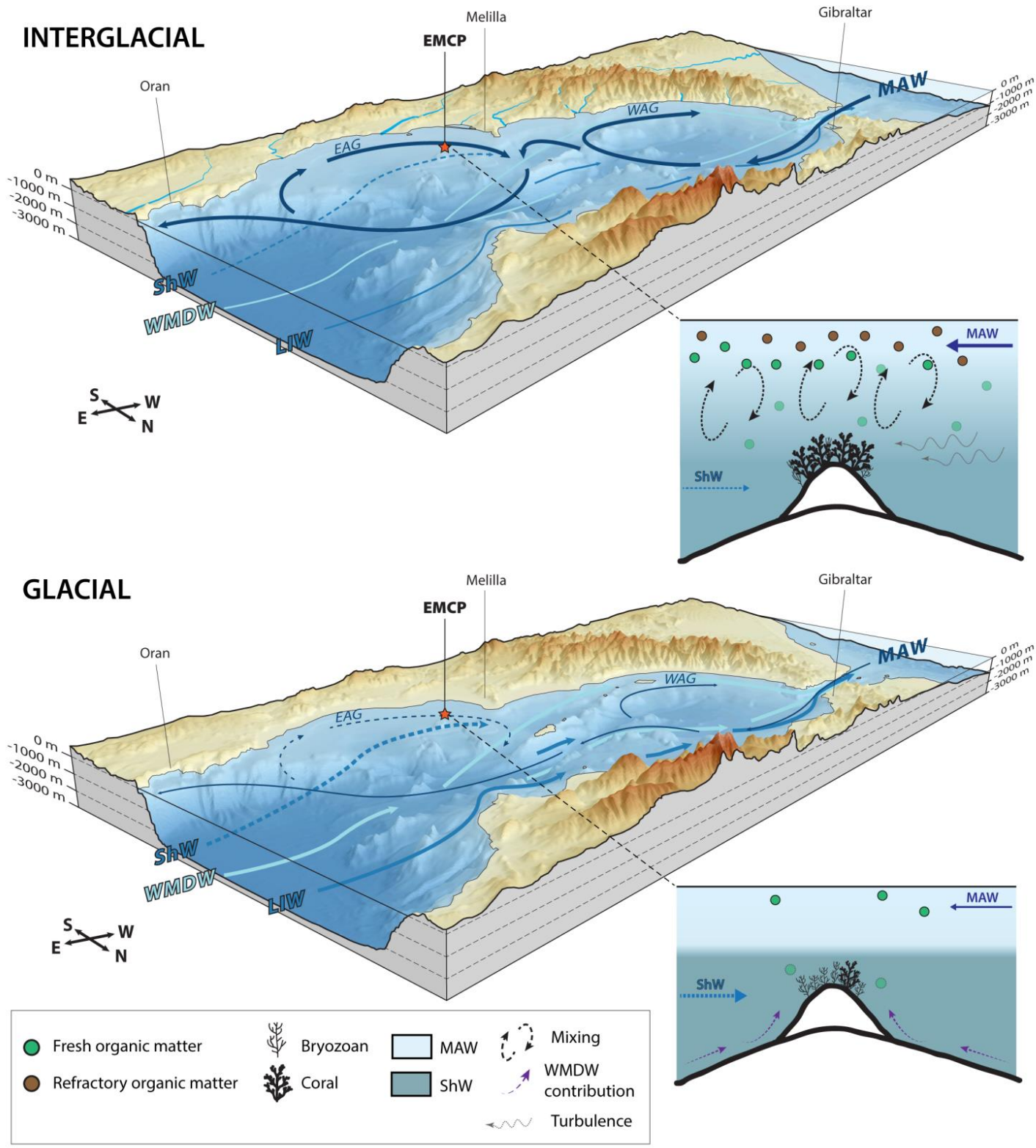
https://doi.org/10.5194/cp-2020-82

Preprint. Discussion started: 26 June 2020

(c) Author(s) 2020. CC BY 4.0 License.

Figure 10. Three dimensional diagrams and schematic models illustrating the differences between interglacial and glacial periods and the response of the benthic community at Brittlestar Ridge I. Water masses discussed in the text are illustrated (MAW: Modified Atlantic Water, LIW: Levantine Intermediate Water, ShW: Shelf Water; WMDW: Western Mediterranean Deep Water) as well as the Western Alboran Gyre (WAG) and Eastern Alboran Gyre (EAG). The flow strength of each water mass is depicted by the thickness of the arrows. The red star indicates the location of the East Melilla Coral Province. The position of the EAG and WAG is based on observations made by Lanoix (1974), La Violette (1983), and Viúdez and Tintoré (1995). Sea level of interglacial periods corresponds to the current sea level, whilst a $100 \mathrm{~m}$ lower sea level stand, following observations made by Rabineau et al. (2006), illustrates glacial periods. The LIW, ShW and WMDW flows follow the observations made by Ercilla et al. (2016). They have been simplified and thus do not represent their exact dynamics. The schematic models are not to scale, although relative depth limits between MAW and LIW have been respected. GEBCO_2019 gridded bathymetric data was used to construct the diagrams. 
https://doi.org/10.5194/cp-2020-82

Preprint. Discussion started: 26 June 2020

(C) Author(s) 2020. CC BY 4.0 License.

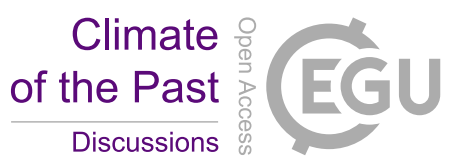

\begin{tabular}{lllllll}
\hline LAB ID & $\begin{array}{l}\text { Depth } \\
(\mathrm{cm})\end{array}$ & $\begin{array}{l}{ }^{14} \mathrm{C} \text { age } \\
(\mathrm{BP})\end{array}$ & $\pm 1 \sigma$ & $\begin{array}{l}2 \sigma \text { lower } \\
(\text { cal years BP) }\end{array}$ & $\begin{array}{l}2 \sigma \text { upper } \\
(\text { cal years BP) }\end{array}$ & $\begin{array}{l}2 \sigma \text { median }(\mathrm{cal} \\
\text { years BP })\end{array}$ \\
\hline ETH-87743 & 2 & 5777 & 25 & 5580 & 5920 & 5760 \\
ETH-87744 & 37 & 22811 & 78 & 25970 & 26530 & 26220 \\
ETH-87745 & 87 & 27587 & 124 & 30730 & 31160 & 30950
\end{tabular}

Table 1. Radiocarbon ages of epibenthic foraminifera (species selected: Cibicides lobatulus, Cibicides refulgens and Discanomalina coronata). Ages are corrected for a reservoir age of $390 \pm 80$ years (Siani et al., 2000).

1320

1325

1330

1335

1340 


\begin{tabular}{lllllllllllllll}
\hline LAB ID & $\begin{array}{l}\text { Depth } \\
(\mathrm{cm})\end{array}$ & $\mathrm{S}^{(1)}$ & $\begin{array}{l}\text { Age } \\
(\mathrm{ka})\end{array}$ & \pm & $\begin{array}{l}\mathrm{Age}^{(2)} \\
(\mathrm{ka})\end{array}$ & \pm & $\begin{array}{l}{ }^{238} \mathrm{U} \\
(\mu \mathrm{g} / \mathrm{g})\end{array}$ & \pm & $\begin{array}{l}{ }^{232} \mathrm{Th} \\
(\mathrm{ng} / \mathrm{g})\end{array}$ & \pm & $\begin{array}{l}\delta^{234} \mathrm{U} \\
(\%)\end{array}$ & $\begin{array}{l}\delta^{234} \mathrm{U}_{\mathrm{i}} \\
(\% \mathrm{o})\end{array}$ & \pm \\
\hline IUP- 8500 & 3 & $M$ & 6.34 & 0.029 & 6.32 & 0.030 & 4.3377 & 0.00037 & 0.4311 & 0.00140 & 147.22 & 0.66 & 149.88 & 0.67 \\
IUP- 8501 & 36 & $D$ & 14.31 & 0.047 & 14.30 & 0.049 & 3.4367 & 0.00012 & 0.3254 & 0.00084 & 145.33 & 0.64 & 151.33 & 0.67 \\
IUP- 8503 & 158 & $D$ & 52.57 & 0.19 & 52.24 & 0.22 & 3.7330 & 0.00013 & 4.8320 & 0.01200 & 123.72 & 0.83 & 143.41 & 0.96 \\
IUP- 9310 & 201 & $D$ & 53.07 & 0.12 & 53.04 & 0.13 & 2.6348 & 0.00008 & 0.3418 & 0.00059 & 126.01 & 0.45 & 146.39 & 0.53 \\
IUP- 8504 & 390 & $D$ & 76.44 & 0.29 & 76.43 & 0.29 & 3.6896 & 0.00011 & 0.1328 & 0.00039 & 115.92 & 0.67 & 143.86 & 0.84 \\
IUP- 9183a & 390 & $D$ & 75.66 & 0.20 & 75.65 & 0.17 & 3.7004 & 0.00016 & 0.1763 & 0.00046 & 117.75 & 0.49 & 145.83 & 0.61 \\
IUP- 9312 & 412 & $D$ & 97.58 & 0.23 & 97.54 & 0.24 & 3.6265 & 0.00012 & 0.4572 & 0.00069 & 112.50 & 0.61 & 148.21 & 0.81 \\
IUP- 9313 & 507 & $D$ & 130.7 & 0.45 & 130.7 & 0.46 & 3.4073 & 0.00015 & 0.3844 & 0.00072 & 105.96 & 0.85 & 153.30 & 1.25 \\
IUP- 8505 & 748 & $D$ & 194.8 & 1.40 & 187.5 & 4.2 & 3.5659 & 0.00220 & $102.38^{(4)}$ & 0.27000 & 95.01 & 0.84 & $161.40^{(3)}$ & 2.40 \\
IUP- 9184b & 756 & $D$ & 181.9 & 0.79 & 181.9 & 0.78 & 2.8694 & 0.00013 & 0.6018 & 0.00099 & 102.72 & 0.79 & $171.74^{(3)}$ & 1.40 \\
IUP- 9314 & 862 & $D$ & 265.7 & 2.10 & 265.7 & 2.4 & 3.4662 & 0.00018 & 0.6693 & 0.00150 & 70.40 & 1.10 & 149.10 & 2.60 \\
IUP- 8507 & 921 & $D$ & 304.2 & 4.80 & 304.2 & 4.9 & 3.0370 & 0.00012 & 0.1176 & 0.00044 & 63.32 & 0.68 & 149.60 & 2.60 \\
IUP- 9185c & 921 & $D$ & 312.1 & 3.40 & 312.1 & 3.0 & 3.3567 & 0.00016 & 0.2789 & 0.00061 & 58.58 & 0.77 & 141.50 & 2.20
\end{tabular}

Table 2. Details of Uranium-series isotope measurements (U/Th) carried out on 10 coral fragments. a) replicate of IUP-8504; b) replicate of IUP-8505; c) replicate of IUP-8507. Brackets denote activity ratios. All errors are $2 \sigma$ of the mean analytical uncertainty. Ratios determined using a Th-U spike calibrated to a secular equilibrium reference material (HU-1 at the IUP). Uncorrected, closed-system age calculated using the decay constants of Jaffey et al. (1971) for ${ }^{238} \mathrm{U}$ and Cheng et al. (2000) for ${ }^{230} \mathrm{Th}$ and ${ }^{234} \mathrm{U}$. Ages are reported relative to the date of analysis, from year 2017 (IUP-8500 to IUP-8507) and year 2018 (other samples), and do not include uncertainties associated with decay constants. ${ }^{(1)}$ Coral species: M: Madrepora oculata; D: 1355 Desmophylum pertusum. ${ }^{(2)}$ Ages corrected for the contribution of initial ${ }^{230} \mathrm{Th}$ based on an estimated seawater $\left({ }^{230} \mathrm{Th} /{ }^{232} \mathrm{Th}\right)$ activity ratio of $8 \pm 4 .{ }^{(3)}$ Significantly elevated $\delta^{234} U_{\mathrm{i}}$ if compared to the present day seawater value of $146.8 \pm 0.1 \%$, possibly indicative of U-series open system behaviour. ${ }^{(4)}$ Samples containing strong residual amounts of non-carbonate contamination leading to high ${ }^{232} \mathrm{Th}$ concentrations and thus age corrections. 